\title{
Across the universe of shale resources-a comparative assessment of the emerging legal foundations for unconventional energy
}

\author{
Peter Cameron, University of Dundee \\ Juan Felipe Neira Castro, Externado University \\ Toma's Lanardonne, laywer, Martinez de Hoz \& Rueda, Buenos Aires \\ and Geoffrey Wood, University of Stirling
}

\section{ABSTRACT}

Outside the US, the commercial development of shale gas and oil will need to overcome significant legal and regulatory challenges if it is ever to take off. This study identifies several key features that have contributed to shale's economic success in the US and applies them to three country settings where policy decisions have been taken to advance a shale resources agenda: Argentina, Colombia and the United Kingdom. Each country is at an initial stage in the development of its resources and has explored various legal instruments to advance its policy aims. In reviewing their experiences, we may be able to identify the emergence of a dedicated body of good or best practices. The study confirms that governments tend initially to rely heavily on established hydrocarbons regulatory approaches, where they exist, but that these quickly prove fragile or insufficient, and need to be supplemented by new measures and institutions targeted specifically at meeting the challenges arising from ownership, infrastructure (including local content) and consent which may otherwise inhibit investment in this energy sector.

\section{INTRODUCTION}

Some years ago, the idea that unconventional oil and gas resources could be developed outside of the USA and Canada, triggering similar transformative effects for the economies concerned, caught the imagination of policy-makers, international organizations and researchers. ${ }^{1}$ Evidence of unconventional resources ${ }^{2}$ in abundant quantities exists in many parts of the world. If large-scale development were to happen outside of North America, it would constitute a new phase in the commercial development of shale gas and oil: we might call it Shale 2.0. Undoubtedly, this would

\footnotetext{
${ }^{1}$ For examples of this body of literature, see Grant Mark Nuelle, 'Prospects for Shale Development Outside the USA: Evaluating Nations' Regulatory and Fiscal Regimes for Unconventional Hydrocarbons' (2015) 8 JWELB 232-68; Susan L Sakmar, 'The Global Shale Gas Initiative: Will the United States be the Role Model for the Development of Shale Gas around the World?' (University of San Francisco Law Research Paper No 2011-27). ${ }^{2}$ Usually, this comprises shale gas, tight gas, shale oil, coal bed methane, hydrates and biogenic gas. The term 'unconventional' indicates that these resources are not capable of being extracted by drilling alone. They therefore take the extraction process closer in the direction of manufacturing, since they require the technologies of hydraulic fracturing and horizontal drilling: see P Stevens, Parliamentary Evidence (Chatham House 2011). In general, they also have higher capital intensity and operating costs than conventional resource activity, as well as greater water consumption and chemical use.
} 
occur only if certain regulatory conditions were met, reflecting the very different and diverse circumstances of countries outside of North America, and the impacts of Shale 1.0. Yet, whatever the initial expectations of policy-makers and investors, this further, 'transnational' phase has yet to happen. Despite evident interest among many governments in exploring the potential for unconventional resource development, and among a few investors, commercial activity has been evident in only a very few locations and on a large scale, mostly in one, the US.

Two of the more commonly cited reasons for this lack of 'take-off' are the opposition from activist groups to such development in most countries with prospective resources (sometimes described in shorthand as the industry's lack of a 'social licence to operate'), ${ }^{3}$ and for a time the coincidental occurrence of a sharp decline in oil and gas prices between 2014 and 2017, leading to reduced interest in high-cost forms of energy. ${ }^{4}$ Between 2014 and 2016, upstream oil and gas investment declined by 44 per cent, but in 2017 there was a 53 per cent increase in shale investment in the US. ${ }^{5}$ If the latter source of constraint to shale activity proves to be only a temporary one, the former is unlikely to be so transient for countries outside of the USA. ${ }^{6}$

This study is directed at the legal and regulatory variable in the attraction of investment in Shale 2.0. With its promise of enhancing energy independence, few would be so bold as to rule out the possibility that in some form and at some time it 'might' happen. Indeed, by 2018 some evidence of a potential Shale 2.0 is already emerging. ${ }^{7}$ With appropriate legal conditions, large-scale

\footnotetext{
${ }^{3}$ Don C Smith, Jessica M Richards and RJ Colwell, "Where "shale" We Go from Here: Opportunities and Challenges in Shale Plays Located Outside the USA' (2017) 10 JWELB 159-219.

${ }^{4}$ This affects unconventional resources since they have costs attached to a lack of infrastructure and water availability, as well as swift production times, to name a few factors.

${ }^{5}$ International Energy Agency, World Energy Investment 2017, 11.

${ }^{6}$ In the North American context, the first known fracking arbitration involving NAFTA art 1128 commenced in 2013. Lone Pine Resources $v$ Canada concerns a claim by a US-registered company that the revocation of an exploration permit by the Province of Quebec amounts to an expropriation of its rights and requires compensation. Both the Governments of the US and Mexico have made submissions which are in the public domain and which appear to support the Canadian Government position (Investment Arbitration Reporter, 22 August 2017). The case is ongoing.

${ }^{7}$ Diverse examples of how Shale 2.0 might emerge include: evidence of very large shale oil deposits in Bahrain (Oil and Gas Journal, 16 April 2018); increasing shale gas production in China with 700 wells forecast between 2018 and 2020 (Reuters, 16 April 2018), lifting of a moratorium on fracking in Australia's Northern Territory
} 
investment in developing these resources may well take place. In its focus on the legal and regulatory variable, this study adopts a comparative approach, using several case studies to illustrate how particular legal, contractual and regulatory mechanisms have been drawn on in common and civil law jurisdictions, and how countries at dissimilar stages of development of their unconventional resources, have created strategies to stimulate investment and to regulate the operations related to these resources.

In terms of our structure, we provide a brief overview of Shale 1.0 (Section 2), in time commencing around 2002 and ending with the oil price collapse in 2014. The idea is an analytical construct, intended to capture events and expectations that contrast with a later period of reassessment and transition to Shale 2.0. Several commentators have sought to identify and assess the conditions behind the US success in Shale 1.0, and to ask which ones were essential and whether some or any of these were or are present in other countries. The US experience occupies centre stage in Shale 1.0 not only existentially but also because of external perceptions of its experience, characterized by initial lofty expectations and subsequent scepticism. The mixture of positives and negatives is important. In the absence of alternative national experiences, the question became one of whether the US experience made it a 'role model' or a unique case. ${ }^{8}$ Even at an early stage, it was clear that some features were unique to this setting. ${ }^{9}$ It is the 'base jurisdiction' for our study.

The core of our article (Sections 3-5) is an examination of three countries that have taken policy decisions to advance a shale resources agenda, but which reflect dissimilar stages in the development of these resources. In each case, the subsoil minerals are publicly owned, the State has a pervasive role in hydrocarbons activity and to a greater or lesser extent conventional hydrocarbons

(Financial Times, 17 April 2018), and the UK's first exploration well drilled by Cuadrilla in April 2018: <https://cuadrillaresources.com/media-resources/press-releases/> accessed 12 July 2018.

${ }^{8}$ See citations in Notes 1 and 2, and The Wall Street Journal. IEA Sees Spread of Shale Gas Revolution Before the End of the Decade. 17 June 2014. <https://www.wsj.com/articles/iea-sees-spread-of-shale-revolutionbefore-end-of-decade-1402988483> accessed 12 July 2018.

${ }^{9}$ For example, the report by Chatham House: Paul Stevens, The 'Shale Gas Revolution': Hype and Reality? (Chatham House 2010) and, with greater emphasis on the downside of shale developments, (2012) The Shale Gas Revolution: Developments and Changes. 
activity is already established under an officially sanctioned regulatory system. Since our interest lies in the kinds of legal instrument and related good industry practices that make unconventional resource development possible, we have chosen countries that have a positive policy towards this new industry. We are aware that other countries have taken a different approach, prohibiting its development. Our selection does not involve making a judgment for or against the development of shale gas or oil. Rather, it follows from our research goal of exploring the initial legal instruments and emerging practices that are deemed appropriate to this still relatively new kind of hydrocarbons operations.

The countries we have selected for our study are threefold. First, there is Argentina, the country which is outside of the USA probably has the most proven resources of unconventional hydrocarbons in the world, mostly located in a single geological formation, known with the unpromising name of 'Vaca Muerta' or 'Dead Cow'. Currently, Argentina is one of a handful of countries in the world that has unconventional hydrocarbons 'in production'. Its approach and its practices therefore make it an ideal case for studying practices that are likely to become a part of Shale 2.0. Secondly, we have selected Colombia, a country like Argentina with a civil law system, and one which has identified substantial resources to be exploited. It is developing a legal framework to facilitate this and is planning for exploration and production. Finally, we have selected The UK, a common law country, ${ }^{10}$ which became one of the first countries outside of the US to drill exploration wells in 2011; subsequently, a variety of obstacles from local government reviews to decisions to impose moratoria and even to ban shale gas developments, have slowed plans to drill wells and build a new industry.

The case studies draw upon the synthetic analyses of national experts in energy law from the above three countries. Each case study covers five broad issues relevant to Shale 2.0 in a country

\footnotetext{
${ }^{10}$ Scotland has a mixed common and civil law system but since it has effectively banned unconventional hydrocarbons activity, it is not considered in any detail in the parts of this paper that address the UK.
} 
setting: how the country and particularly its government reacted to Shale 1.0; what the existing hydrocarbons regime was like; what measures were taken to promote and regulate unconventional resources; the challenges that became evident and what solutions were developed locally to meet them, and an assessment of the emerging shape of regulation for Shale 2.0. Within each heading, there is some variation in the coverage given the evolving nature of the subject matter and the impact of circumstances, policy priorities or the state of sector development. Some concluding comments are made based on a comparative analysis of common features and contrasting approaches to the regulation of unconventional hydrocarbons (Section 6).

Other countries might have been chosen of course, even though very few provide examples of production activity. A criterion that influenced our choice was the availability of reliable data relevant to an analysis of a regulatory regime for unconventional hydrocarbons. China has extensive deposits of shale gas and considerable potential, but we did not feel our access was likely to yield the quality of data that we were seeking. ${ }^{11} \mathrm{~A}$ further consideration was whether the hydrocarbons regime in a country was open to international investment: regimes which are closed are not likely to be influential on the development of transnational practice in this area.

The comparisons and contrasts drawn out through these three country studies may yield fresh insights into this question of investment promotion in what we have called the Shale 2.0 phase. In that sense, we aim to contribute to a growing body of multi-disciplinary scholarship

\footnotetext{
${ }^{11}$ The emerging regime is strongly supported by both Central and Provincial government authorities through development planning and subsidies, with engineering services and infrastructure construction being built up to achieve energy security goals. BP appears to be the only IOC involved, with activity in shale gas dominated by Sinopec rather than Petrochina, the main gas producer (and BP's partner). High costs, plus the need to drill beyond 3500 metres and the location of shale in blocks already licensed for conventional resource development are among the blocks to rapid development. For further published analysis, see Jianghua Chen, 'Shale Gas Exploration and Development Progress in China and the Way Forward' (2018) IOP Conference Series: Earth Environ Sci 113 012178; PD Farah and R Tremolada, 'A Comparison between Shale Gas in China and Unconventional Fuel Development in the United States: Water, Environmental Protection, and Sustainable Development' (2016) Brooklyn J Int'I Law 580-654. Older, but informative analyses include: D Sandalow D and others, 'Meeting China's Shale Gas Goals' Columbia Center on Global Energy Policy Research Report (2014), and Fan Gao, 'Will there be a Shale Gas Revolution in China by 2020?' Oxford Institute for Energy Studies NG 61 (2012).
} 
surrounding unconventional oil and gas and the technologies that support it. Our aim of contributing to it springs from a belief that the body of knowledge required-if investment in the complex Shale 2.0 context is ever likely to materialize-will be richer, deeper and more reflective in character than was evident in the making of Shale 1.0. One of the outcomes of that research could be the development of a body of standards, or 'best international industry practice' that may assist governments that seek to design or to benchmark regulatory regimes in this area.

By way of a caveat, it should not be thought that the authors are unaware of the arguments 'against' the development of shale oil and gas or that they are 'advocates' of such development in general or in any special context. Within the USA, the heart of Shale 1.0, there are influential bodies in several States that have acted to limit shale development, taking a critical view of the balance of costs and benefits. Indeed, there is a long tradition of imposing strict limits to conventional hydrocarbons or mining activities in certain areas such as national parks or urban areas with dense populations. The idea of imposing constraints is neither new nor unreasonable. It does not preclude development of hydrocarbons in other less socially or environmentally sensitive areas. In this case, the relative novelty of the application of several technologies, and their continued evolution and enhancement, means that regulation of unconventional hydrocarbons is likely to require periodic review to ensure it is appropriate to the kind of operations involved in their development. However, at this stage very little regulation has in fact been put in place outside of North America, and what exists is far from being tried and tested. The focus of this study lies then not in assessing the adequacy of an 'established' form of regulation but in tracking the evolution of national practices as the source of an emerging international best practice in what is still a relatively new area of energy law. 


\section{SHALE 1.0 : THE US AS MODEL OR WARNING?}

\section{Shale 1.0's beating heart}

The narrative of unconventional energy's growth in the US is a compelling one and has often been described. ${ }^{12}$ It forms an essential part of an already considerable literature on the various economic, technological and legal impacts of Shale 1.0. ${ }^{13}$ Its impact on the US economy has been dramatic: from being a country that was increasingly dependent on imports of oil and gas throughout the later 20th century, it has been transformed by the development of domestic unconventional oil and gas resources into one that is self-sufficient, and export-oriented. Its wider impacts on US industry have also been much commented upon. On some estimates, energy costs to US industry have dropped by a third while European competitors faced increases of more than 50 per cent. ${ }^{14}$ The increased demand for metallic products, such as pipes and other equipment to allow the metallurgical industry to grow at a rapid rate: by 2011 'US Steel invested \$95 million in an Ohio plant to help meet the demand from shale gas extraction activities .... Vallourec was spending $\$ 650$ million on a new plant in Ohio to supply steel pipe for companies extracting shale gas'. ${ }^{15}$ At the same time, opposition to the new industry has been intense and vocal from the outset, particularly in the more densely populated parts of the USA, driven by environmental concerns and leading to a lack of a 'social licence to operate' in some areas. ${ }^{16}$

\footnotetext{
${ }^{12}$ For example, Gregory Zuckerman, The Frackers (Portfolio Penguin 2013); and Susan L Sakmar, 'The Global Shale Gas Initiative: Will the United States be the Role Model for the Development of Shale Gas around the World?' University of San Francisco Law Research Paper No 2011-27.

${ }^{13}$ On taxation of shale gas, there is a comprehensive working paper from the International Monetary Fund: $P$ Daniel and others, 'How Should Shale Gas Extraction be Taxed?'

(<http://www.imf.org/en/Publications/WP/Issues/2017/11/16/How-Should-Shale-Gas-Extraction-Be-Taxed45410> accessed 12 July 2018). On the wider economic issues, examples are C Hausman and R Kellog, 'Welfare and Distributional Implications of Shale Gas'. Working Paper 21, 115, National Bureau of Economic Research, Cambridge, MA (2015); C Mason, L Muelenbachs and S Olmstead, 'The Economics of Shale Gas Development' (2015) 7 Annual Review of Resource Economics 269-89. Impacts on energy markets are discussed in P Brehm, 'Natural Gas Prices, Electricity Generation Investment, and Greenhouse Gas Emissions' Working Paper, University of Michigan (2015), and J Kepes, B Rodgers and P van Meurs, 'Gas Prices, other Factors indicate Changes in North American/Shale Play Fiscal Systems' (2011) 109 Oil and Gas Journal 56-66. Timothy Fitzgerald discusses the technological aspects of hydraulic fracturing: 'Frackonomics: Some Economics of Hydraulic Fracturing' (2013) 63 Case Western Reserve L Rev 1337-62.

${ }^{14}$ Ventocilla (2016), JWELB.

${ }^{15}$ PWC. Shale Gas: A renaissance in the US Manufacturing. 2011.

${ }^{16}$ The social licence to operate is the issue that Don Smith and others (2017) focus on and propose a model based on Colorado state practice to address this.
} 
This sudden complex change in the energy mix of the largest energy consumer in the world not only attracted international attention but was also coupled with publication of data suggesting that similar geological formations were present in many other parts of the world. ${ }^{17}$ If the geology was indeed favourable in terms of reserve quantity and accessibility, what conditions were required to replicate the shale energy revolution outside of North America, and would governments act to facilitate it? For many a policy-maker in energy importing countries, it seemed to offer a way of providing a secure and constant supply of hydrocarbons to their domestic industries and homes, and yet avoid the costs of importing energy. At the same time, media reports of popular concerns about its potential impacts encouraged many governments to impose prohibitions and similar constraints on prospective operations: in Bulgaria, France, Germany, Romania and South Africa, and at a subnational level in Australia, Ireland, Spain, Switzerland, the UK (Scotland, Wales) and the USA (including New York, Vermont and cities and counties in California, Colorado, Texas and Ohio).

An enquiry into the ingredients for success and whether they could be replicated elsewhere lay behind much of the literature and media coverage of the 'Shale Revolution'. Apart from geology, the key criteria seemed to be: economics, infrastructure availability, equipment and crucially, whether such activity was to be permitted by the government concerned. In the diverse and abundant commentary that has followed, we might distinguish two broad approaches: ${ }^{18}$ the first identified and examined the factors behind its success in the US (and largely ignored developments in Western Canada) and then asked how many of these were available 'outside' the US and whether the absence of any of them was significant; the second adopted a different approach and focussed on what 'success' meant in the US context, with a focus on the social cost and sometimes the tacit

\footnotetext{
${ }^{17}$ The US Energy Information Administration analysed 48 shale gas basins in 32 countries and based on its estimates of technically recoverable reserves of shale gas in Europe, the European Centre for Energy and Resource Security argued that they had the potential to meet European gas demand for at least another 60 years: Financial Times, 12 May 2011: Critics try to stifle the shale gas revolution. This data is probably incomplete and understates potential in the Middle East and some other source rocks for shale gas and shale oil. However, for data gathering purposes the next question is how much of this is commercially extractable at a certain price.

${ }^{18}$ See the citations in foregoing footnotes $1,4,9$ and 12.
} 
question: can it last? While it is the first of these that concerns us in this article, in the next few paragraphs we shall briefly review each of these perspectives and what insights they have yielded.

\section{Characteristics of Shale 1.0}

The eight principal factors that contributed to the Shale Revolution in North America are usually thought to be the following ${ }^{19}$ :

- Private ownership of subsurface mineral rights - which permits surface access and limits legal challenges to rapid development (enabling legislation and regulations may serve to replicate this as an incentive but is unlikely to allow for the same degree of rapid development);

- Independent gas companies with the necessary technical knowledge and the incentive to apply or develop it; and service companies. . .

- Pre-existing pipeline infrastructure and capacity

- Fairly abundant water supplies

- Low population density-which limits public opposition

- Deep capital markets

- High natural gas prices, and gas demand

- Royalties and taxes, which are sensitive to the unconventional net cash flow profile and cost base.

The use of combined techniques, such as hydraulic fracturing, horizontal drilling and seismic mapping, became a general practice in different areas of the USA during the decade from 1990 and led to better rates of production in 2003 and $2004 .^{20}$ Unconventional resources had long been known but what was new was the application of hydraulic fracturing involving the opening of shale rock by means of the fracturing, then injecting thousands of tonnes of water, sand and other additives underground at high pressure. However, it was not until 2007 that a substantial growth in the production of hydrocarbons started to become relevant at the level of the national energy mix and initiated what at the time was often referred to as the 'shale revolution'. At that time, production of shale gas reached 8 per cent of the total natural gas production in the USA, with significant impacts on the industry, the prices and the economy. ${ }^{21}$

\footnotetext{
${ }^{19}$ The following list is a synthesis of similar lists in publications by P Stevens (2010) and P Daniel and others (2018).

${ }^{20}$ Around 2 billion cubic feet (BcF) per day from the Barnett Shale formation, overtaking the production from more traditional areas in the Appalachian basin in Ohio or the Michigan Basin.

${ }^{21}$ Last visited: <http://www.eia.gov/totalenergy/data/annual/pdf/sec2.pdf> accessed 12 July 2018.
} 
A switch from coal powered generation plants to gas powered ones followed: in 2001 only 17 per cent of the power generated used gas as fuel, while coal was the main source for production with 51 per cent; by 2012, 31 per cent came from gas and 36 per cent came from coal. ${ }^{22}$ In 2010 alone, $2200 \mathrm{MW}$ of gas powered energy was introduced into the market, an equivalent of 84 per cent net new capacity. ${ }^{23}$

While other factors may have affected the industry decision to change its fuel for electricity generation, the reduced price of gas was one of the main drivers for this change. Another contributing factor may have been the impact of policies to reduce $\mathrm{CO}_{2}$ emissions, which was adopted by environmental authorities in the US; this factor makes gas more advantageous than coal, from an environmental perspective. Academics have measured the potential impact that the reduction of emission by the changing on fuel for the generation of power to be between 35 per cent and 50 per cent from the national peak in $2005 .{ }^{24}$

Another element that has been attributed to the increase of gas production caused by the shale gas exploration and production, is a phenomenon of regeneration and improvement in some industries that were in decline or had disappeared in the USA. The activities and effects of shale gas activity affected the economic performance of the states where the major formations were located, and where the activity and production were occurring. Increases in employment related to the industry or improvements on the general economic performance of towns, counties and states, are some of the positive effects that shale gas brought to the communities.

Several studies have analysed the economic impact that the states and towns involved in the shale gas revolution have experienced. Some of them have initiated arguments on how the

\footnotetext{
${ }^{22}$ A Yanagisawa, 'Impacts of Shale Gas Revolution on Natural Gas and Coal Demand' (2013) IEEJ. Another contributory factor is the need for renovation of non-efficient coal-powered plants. Due to several environmental regulations issued by the Environmental protection Agency, as well as the increase on efficiency of combined cycle gas turbine powered plants, has made that the switch from coal to gas, has been welcomed within a context of favourable fuel (gas) price.

${ }^{23} \mathrm{~J} \mathrm{Broderick}$ and K Anderson, 'Has US Shale Gas Reduced CO2 Emissions' Tyndall Centre, 2012.

${ }^{24}$ ibid.
} 
measurement of the positive effect has been done, and how much of the actual benefit has a longlasting effect on the economy. ${ }^{25}$ Other studies with a more optimistic view base their conclusions on the increase on jobs, tax revenues and local or regional gross product.

An example of this is the increase in number of jobs in the state of Pennsylvania with 29,000 new jobs in 2008 and tax revenues of $\$ 238$ million. A more general approach of the development of the Marcellus shale formation (including West Virginia and Pennsylvania), improved the gross regional product by $\$ 4.8$ billion, created 57,000 new jobs and brought $\$ 1.7$ billion in local, state and federal taxes, all in 2009. Texas and the development of the Barnett formation is another example where clear numbers illustrate the economic prosperity that shale gas has brought to some of the regions where it is developed. In Texas, in 2011, the regional output related with shale gas is of $\$ 1.11$ billion equivalent to 8.1 per cent of the region's economy, as well as 100,000 jobs, equivalent to 10 per cent of the employment of the region. ${ }^{26}$

\section{Critique of Shale 1.0}

Two strands of criticism emerged at an early stage. Too many of the ingredients of success were specific to the North American context and could not be replicated elsewhere. Furthermore, there were important negative environmental impacts of the shale technologies which would undermine social acceptance.

On the first strand in the shale critique, there are many surface challenges that may prevent widespread development of shale potential in the US and beyond. ${ }^{27}$ If one looks to the US effort, the scale of the practical challenge becomes evident. In terms of the capital commitment, the success rate is around 10 per cent in developing new shale deposits or 'plays' in the US, with each play typically requiring 50-100 wells to 'crack the code' to commerciality and taking between 3 and 5

\footnotetext{
${ }^{25}$ A Munasib and D Rickman, 'Regional Economic Impacts of the Sale Gas and Tight Oil Boom: A Synthetic Control Analysis' (2015) 50 Regional Science and Urban Economics.

${ }^{26}$ B Sovacool, 'Cornucopia or Curse: Reviewing the Costs and Benefits of Shale Gas Hydraulic Fracturing (fracking)' (2014) 37 Renewable and Sustainable Energy Reviews.

27 Moyes \& Co: AIPN Model Contracts Workshop, June 2015: Presentation on Unconventional Resources.
} 
years. Most of the plays fail in a range of between 5 and 15 wells drilled. For individual companies, this is a demanding requirement to have both capacity for the capital load and investors patient enough to wait for a return once commerciality is proven. For countries outside the US, this context is even more off-putting. One review of several areas: Argentina (Vaca Muerta), Australia (Cooper Basin) and China (Sichuan), concluded that outside of North America shale once produced is likely to prove expensive.

The regulatory approach is replete with challenges if the US experience is an indicator. Firstly, there is a need to adapt any existing regime for conventional resources, including provision for an ability to hold undeveloped acreage positions and drill as needed to provide hydrocarbon volumes for a period of 40-60 years. Secondly, the regime needs to be able to process a high volume of permits and the relevant paperwork for drilling, completion and pipeline construction. Local councils need to be supportive of this activity. This social acceptance is key since the projects absorb copious quantities of sand and water and truckloads of equipment and liquids, causing significant disruption unless the areas are remote. Early evidence from the US suggests that the reinjection of produced water underground through disposal wells is responsible for the measurable rise in the number of earthquakes with a magnitude of 3.0 in the State of Oklahoma, for example. ${ }^{28}$

However, there was also concern about negative effects peculiar to this manner of developing unconventional hydrocarbons. The main ones were: the risk of ground and surface water contamination arising from well integrity; the intense use of resources such as water and land; and the risk that induced seismic activity would cause earthquakes.

Several concerns over the protection of aquifers and water resources have been identified by citizens and academics. Some argue that the fracturing process or the lack of stability of the wells, could lead to the contamination of water supplies from the filtration of chemical fluids used in the

\footnotetext{
${ }^{28}$ ibid. From zero per annum the number of earthquakes increased to 584 in 2014.
} 
process. ${ }^{29}$ Others have raised concerns on the possibility of methane leaks into the atmosphere, creating another risk of air pollution. ${ }^{30}$

Other potential risks associated with the production of unconventional hydrocarbons refer to the substantial use of water for the fracturing work, and to the use of that water, after it has been injected into the ground. The management and potential reuse of the water has caused concerns amongst the population and some organizations. ${ }^{31}$

The final disposition of the produced water has become an issue, and in some states it has been reinjected into the ground. This practice and the fracturing of the underground, has been associated with the increase of tremors and seismic events in some states. ${ }^{32}$

The abovementioned potential risks that have been associated with shale gas resources development have been addressed by federal and state governments. In principle, the development of environmental protection laws, regulations and guidelines can address the above risks, and the ones adopted in the US may provide a lead in their design for application in other jurisdictions. However, from a legal point of view, fracking can also generate litigation such as claims that plaintiffs have suffered personal injuries because of pollutants released because of fracking operations. This could arise from the release of chemical compounds into the air or fracking fluids leaking into the soil and well water. A more complex problem arises from the long-term effects of these processes and the legacy of defunct operations many years later.

\section{What's it all about? Thinking beyond Shale 1.0}

In using the term Shale 1.0, we are not only characterizing the immense increase in production in gas and oil that was evident in the USA, and the legal frameworks that made it possible. In our view, it

\footnotetext{
${ }^{29}$ Vengosh and others, 'The Effects of Shale Gas exploration and Hydraulic Fracturing on the Quality of Water Resources in the USA' (2013) 7 Procedia Earth and Planetary Science.

${ }^{30}$ Carnegie Mellon University. Shale Gas and the Environment: Critical Need for a Government-UniversityIndustry Research Initiative. 2013.

${ }^{31}$ Groundwater Protection council. US Produced Water Volumes and Management. 2012.

${ }^{32}$ WL Ellsworth, 'Injection-Induced Earthquakes' (2013) 341 Science.
} 
also refers to the body of scholarly research and legal analysis that it triggered in many countries.

This involved academics, legal professionals, government bodies, scientific associations,

international organizations and industry associations. The body of knowledge about unconventional resources has grown at an exponential rate in the past decade. Ironically, outside of North America shale activity has evolved at a pace far slower than the volume of literature on the subject. A great deal has been written on the evolving legal regimes in various country settings. ${ }^{33}$

\section{Moving beyond shale 1.0: adapting regulation and contracts}

It is perhaps unsurprising that despite the differences between unconventional and conventional hydrocarbon resources, the legal and regulatory frameworks that have been initially designed for unconventional energy have been closely modelled on their tried and tested counterparts for conventional sources of energy. Since the economics and the extraction techniques are different, it is to be expected that the legal regimes will 'eventually' be adapted to reflect this. Indeed, lawyers, commercial negotiators and advisers with industry clients have been among early commentators on the legal implications of the specific features of unconventional energy resources. ${ }^{34}$ In spite of the fact of state ownership and extensive control in most countries, the design of rules for the energy industry in a new field is not only a matter for governments. Some early attempts at designing common frameworks have already emerged from industry associations and regional bodies.

\footnotetext{
33 There are many examples, but a few are given below: W Baginski, 'Shale Gas in Poland - The Legal Framework for Granting Concessions for Prospecting and Exploration of Hydrocarbons' (2011) 32 Energy L J 145; Mostafa I Elshazly, 'The Legal and Contractual Framework pertaining to the Exploration and Production of Shale Gas in Egypt' (2015) 8 JWELB 385-90; David AW Maloney, 'Unconventional Oil and Gas in Australia: A Case of Regulatory Lag' 33 J Energy \& Natural Resources L 349-404; Brian J Preston, 'Unconventional Natural Gas in the Courts: An Overview' (2014) 32 J Energy \& Natural Resources L 377-424; an overview of the regimes in place in many countries was compiled by the law firm, Baker and McKenzie: Shale Gas: An International Guide (2nd edn 2014).

${ }^{34}$ In a two-part article, Peter Roberts examined how a conventional joint operating agreement would need to be modified to reflect the nuances of an on-land shale gas project: 'UK Shale Gas Prospects - Preparing Bespoke Joint Operating Agreements and Gas Sales Agreements' (2013 and 2014) 31 and 32 J Energy \& Natural Resources L 407-24 and 41-57; the Baker \& McKenzie study on Shale (2014) discusses this as does the guidance to the AIPN UROA (see Trinh Chubbock, 'The First AIPN Model Contract for Unconventional Resource Operations' (2014): <https://www.lexology.com/library/detail.aspx?g=535b3956-b32d-4498-9065f37de5fadb31>) accessed 12 July 2018.
} 
An early example of the focus on specifics of the new unconventional sector was the 2014 Association of International Petroleum Negotiators (AIPN) adaptation of its Model International Joint Operating Agreement (2012) for potential use in connection with unconventional resource deposits. It also issued Guidance on the use of the Unconventional Resources Operating Agreement (UROA). More than 160 industry representatives from 26 countries were involved in drafting this model, the first of its kind. It covers joint operations in shale oil and gas, tight oil and gas, coalbed methane and other unconventional production methodologies involving wellbore operations. The modifications consider key differences unique to unconventional resources such as pilot projects, sub-areas, multipad drilling and production, and other features of horizontal drilling. This was-and is - an attempt to developing in a prospective way a measure of standardization in transnational contractual practice.

Among the features of unconventional resources that require some special consideration by governments in adapting their existing regime design from conventional to unconventional resource development are the following four ${ }^{35}$ :

Operational considerations. The higher density of wells and on-land base for exploration, appraisal, development and production operations leads to a greater demand for land access authorizations and operational permits. A well for shale gas will typically run vertically down to the shale layer for about a mile and then extend horizontally, possibly for as much as two miles, potentially going under the land of many owners.

Environment and social regulation. The potential impact and perceived risks on the surface land, air quality, and underground water resources mean that regulation is required. In practice, the risks of groundwater contamination from the fracking process itself are likely to be less common than those arising from improperly managed sludge and fracking pits and improperly disposed fracking fluids. Such fluids typically contain methane, ethane, and volatile organic compounds, which

\footnotetext{
${ }^{35}$ P Cameron and M Stanley, The Extractive Industries Source Book (The World Bank 2017).
} 
may be hazardous to health if not contained and disposed of during fracking operations. Air pollution may also arise from inadvertent venting of substances into the atmosphere and affecting the quality of air in the surrounding areas.

Fiscal incentives. These are required when the cost of unconventional operations is substantially higher than for conventional ones. This could mean reduced royalty rates, a tax credit or more favourable schemes for cost recovery, and a profit gas split. This approach is less justified if there is an additional profits tax or a profit-sharing scheme in place, because in that event the economic criterion on which it is typically based will allow for an automatic integration of the economic differences between conventional and unconventional gas.

Licensing systems. Adjustments would be needed to existing provisions on exploration and appraisal periods, work commitments, the definition of an unconventional gas field and submission of development plans. Where rights have already been awarded specifically for conventional petroleum or coal exploration and production in a given area, new rules may allow the award of separate rights for unconventional resources. In Indonesia, for example, regulations give a priority access to holders of existing rights if they wish to seek rights over unconventional resources. The PSC for coal bed methane has a term of 30 years, including an initial exploration term of 6 years, which may be extended by four years for assessing the viability of a commercial coal-bed methane project.

Indeed, industry associations have played a key role in establishing a body of good international petroleum practice since the earliest days of conventional hydrocarbons development. In another example of a recent initiative by industry, a body known as the UK Onshore Operators Group (UKOOG) has published the 'UK Onshore Shale Gas Well Guidelines', setting out best practice for shale well operations. ${ }^{36}$

\footnotetext{
${ }^{36}$ UK Onshore Shale Gas Well Guidelines: Exploration and Appraisal Phase, 2013: <http://www.ukoog.org.uk/images/ukoog/pdfs/ShaleGasWellGuidelines.pdf>: 'the initial operations will be treated as a pilot to ensure that high standards of safety and environmental management are achieved and to enable the guidelines to be fully evaluated'. The Guidelines are careful to emphasize that they are limited in
} 
At an early stage the question was raised of whether a regional framework for shale development could emerge on a European basis led by European Union institutions. In 2011, a report was submitted to the European Commission that examined various aspects of unconventional gas in the European context. ${ }^{37}$ No commercial scale shale gas production was in place at the time. The EU had begun deliberations on possible actions to take, probably with the aim of proposing a harmonized regime across the EU. ${ }^{38}$ However, Article 194 of the Treaty for the European Union gives each Member State the right 'to determine the conditions for exploiting its energy sources, its choice between different energy sources and the general structure of its energy supply'. This shared competence between the Member State and the EU institution created obstacles for regulatory action in this new field, ${ }^{39}$ making any binding measures difficult to secure approval for. In January 2014, the European Commission adopted a Recommendation setting out minimum principles for Member States when applying or adapting their legislation on conventional hydrocarbons to shale operations. ${ }^{40}$ The thrust is to safeguard public health, climate and the environment, to ensure that resources are used efficiently and to keep the public informed of the activities. It was adopted according to Article 292 of the Treaty on the Functioning of the European Union (TFEU) and is not

scope to the first two phases of shale activity and are the first iteration, to be modified in the light of knowledge gained from the experience of initial operations.

${ }^{37}$ Philippe \& Partners, Final Report on Unconventional Gas in Europe: 8 November 2011. The main purpose of the Study was 'to analyse how the relevant applicable European legal framework, including environmental law, is applied to the licensing/authorisation and operational permitting for prospection, exploration and production/exploitation of shale gas based on a sample of four Member States, i.e. Poland, France, Germany and Sweden' ( $\mathrm{p} 5$ ). Since that time there has been further research into the European regulatory framework: for example, L Reins, Regulating Shale Gas - the Challenge of Coherent Environmental and Energy Regulation (Edward Elgar 2017).

${ }^{38}$ The European Parliament Briefing of December 2014 summarizes the energy security aspect behind this debate:

<http://www.europarl.europa.eu/RegData/etudes/BRIE/2014/542167/EPRS_BRI(2014)542167_REV1_EN.pdf> accessed 12 July 2018.

${ }^{39} \mathrm{~K}$ de Smedt and A Rigamonti, 'Towards a Common Framework for Shale Gas Extraction in the EU' (2013) 21 Env Liability: Law, Policy and Practice 145-53: 'Ultimately, it will be the Member States that will decide to engage in shale gas exploration and extraction' (at 153).

${ }^{40}$ Recommendation 2014/17/EU: <http://eur-lex.europa.eu/legalcontent/EN/TXT/?uri=uriserv:OJ.L_.2014.039.01.0072.01.ENG\&toc=OJ:L:2014:039:TOC> accessed 12 July 2018. A Communication was issued at the same time, providing background to the Recommendation and its assumptions: COM (2014) 23 final/2: <http://eur-lex.europa.eu/legalcontent/EN/TXT/PDF/?uri=CELEX:52014DC0023R(01)\&from=EN> accessed 12 July 2018. 
legally binding on Member States. Divergent approaches to shale development among the Member States and partners seem very likely to result from this approach, particularly after the impact of the UK exit from the EU.

\section{Conclusions}

From the above overview-which makes no claims to being comprehensive-it should be clear that the body of knowledge that exists for designing laws and key contractual documents for unconventional resource activity is already evolving. The remarkably slow expansion of shale activity almost everywhere in the world contrasts markedly with its resilience in the US. However, there is a difference between a slow emergence and no emergence at all. Despite the many moratoria and prohibitions in countries around the world, there are several areas in which it is being encouraged by governments not least for reasons of energy security policy. The probability that it will not resemble the US industry is hardly an indicator that it will fail to emerge.

In 2018 alone, as prices rise once again, there have been some notable relevant developments. Apart from the discovery of what appear to be significant deposits of unconventional gas in Bahrain, mentioned earlier, there is a growing expansion of shale gas in China and a recent report in the industry's potential in Australia's Northern Territory argued that the risks can be adequately managed. ${ }^{41}$

In the following sections, the legal development of shale resources in three countries will be presented in a case study format, noting how the regulatory structures have evolved and how the authorities have addressed their own local problems to facilitate a contribution of shale to their energy mix.

\footnotetext{
${ }^{41}$ Oil and Gas Journal, 9 April 2018: 'Fracking inquiry report handed to Northern Territory'.
} 


\section{CASE STUDY 1: ARGENTINA}

\section{Reacting to Shale 1.0}

Among the countries that have sought to replicate the US 'shale revolution', Argentina stands out.

The country is ranked in the 'top $5^{\prime}$ in terms of global shale oil and gas endowment and is a potential shale 'giant'. Building on the geology, the government has taken steps to introduce special contractual arrangements for unconventional resource development and generally to provide legal and economic stability to investors. Progress in developing the Vaca Muerte or 'Dead Cow' formation in the Province of Neuquen has been rapid despite logistical issues (infrastructure, skills and the modest size of the oil services sector, for example) and-in the background-some tensions between the federal and provincial authorities over their respective competencies. With the prospect of exporting gas to Chile, the country could become an energy hub in Latin America.

Even while the geology was present from the very beginning in Argentina, the industrycomprising majors and independents-took the view that they had to 'crack its code'. Four years of intense initial exploration followed, with more than 800 drilled wells: 629 with oil/condensate production and 497 all in only one block and 549 operated by the state company, YPF; 137 wells with dry and wet shale gas production, and 98 in effective production. The learning curve of the Vaca Muerta shale play has probably reached its peak. As Table 1 illustrates, productivity rates of horizontal wells aiming to extract hydrocarbons from the 'Dead Cow' have been increasing year on year and match those of the US shale plays.

However, in policy terms Argentina has had to accompany this activity with some significant wider economic reforms to secure further investment into its economy. From 2016 onwards, features of the macroeconomic context included the Administration's settlement of the public debt arising from the 'holdouts', elimination of foreign exchange restrictions, reduction of inflation, and importantly, ensuring that these measures were explained as part of a wider attempt to regain credibility with the international investment community. 
From a sector standpoint, the Government was active in progressing the 'to do list' requested by energy experts and industry players: it introduced a 'contract-for-differences' scheme that guarantees a minimum price for shale or tight gas; it pushed for an amendment to the Collective Bargaining Agreement between oil companies and oil workers that slashes labour costs; it eliminated export taxes on hydrocarbons; it is overhauling the import regime for equipment and consumables required to develop oil fields; and it is investing heavily to improve the roads and railways connecting Vaca Muerta s fields with the supply chain and domestic market.

\section{The legal and policy framework}

Since the first discovery of oil in 1907 there has been an ongoing controversy between the Federal Government and the provinces regarding the eminent domain of the hydrocarbon reserves and the authority to legislate on the matter. The Constitution delegated to the Federal Government (ie Congress and implementing regulations issued by the Executive Branch) the authority to establish the substantive rules governing the exploration and production of crude oil and gas, thus ensuring the uniformity of legislation. ${ }^{42}$ However, despite this clarity about legislative power, the eminent domain of the hydrocarbons reserves has shifted between the provinces and the Federal Government, and this has had practical consequences for the grant of exploitation concessions and exploration permits, the collection of royalties and the level of involvement of the national and provincial authorities. In the most recent iteration of this pendulum swing, a Constitutional amendment in 1994 allowed the provinces to recover ownership rights over the natural resources found in their territory. ${ }^{43}$

Since the enactment of Law 26,197 in December 2006 (the Re-Provincialization Law), the provinces became the enforcement authority of the Federal Hydrocarbons Law $(\mathrm{FHL})^{44}$ within their

\footnotetext{
${ }^{42}$ See art 75 subsection 12 of the Argentine Constitution. The Federal Supreme Court, interpreting this constitutional provision, held that the power delegated to the Federal Government to legislate on mining refers to all types of mines, among which hydrocarbon fields are included (see Rulings 301:341 and 311:1265). ${ }^{43}$ See art 124 of the Argentine Constitution.

${ }^{44}$ Law No $17,319$.
} 
relevant jurisdictions. ${ }^{45}$ While the Re-Provincialization Law expressly maintains the uniformity of substantive legislation by keeping the effectiveness of the FHL and its implementing rules and by requiring the provinces to abide by such regulation, it recognizes several rights as vesting in the Provinces, including the following: ${ }^{46}$

i. To grant new exploration permits and production concessions over the hydrocarbons located within their territories;

ii. To extend the terms of the current and new permits, concessions and contracts;

iii. To approve their assignment;

iv. To revoke the same upon material breaches or causes set forth in the FHL;

v. To impose penalties; and,

vi. To exercise, in general, all the powers inherent to their condition as Enforcement Authority.

The Federal Government preserves all such rights in relation to off-shore blocks beyond 12 miles ${ }^{47}$ Finally, in line with the principle set out in the Constitution and the FHL, the Re-

Provincialization Law vests in the Federal Executive Branch the sole authority to design the federal energy policies. ${ }^{48}$

\section{Regulating to promote unconventional hydrocarbons}

\section{Exploitation concessions}

The FHL conceives a system of exploration permits and production concessions awarded by the State (Federal or Provincial, depending on the location of the deposits), under which companies hold exclusive rights to explore, develop, exploit and take title to the production at the well-head, in consideration for a royalty and the application of the general taxation regime. ${ }^{49}$ As mentioned above, the FHL was amended in 2014 to create a new type of concession: the unconventional exploitation concession.

The procedure for awarding exploration permits and production concessions over new blocks (other than those concessions resulting from an exploration permit or a subdivision of an

\footnotetext{
${ }^{45}$ See art 2 of the Re-Provincialization Law.

${ }^{46}$ See art 2 first and third paragraphs and art 6 of the Re-Provincialization Law.

${ }^{47}$ See art 1 of Federal Hydrocarbons Law as amended by art 1 second paragraph of the Re-Provincialization Law.

${ }^{48}$ See art 3 of the Federal Hydrocarbons and art 2 fourth paragraph of the Re-Provincialization Law.

${ }^{49}$ See ss 2, 3 and 6 of Title II of the FHL.
} 
existing concession) is by means of a public tender, and the criteria for selecting a bid must be the value of the work commitments. ${ }^{50}$ However, leaving to one side any special cases that may involve a bidding process on vacant areas of provenreserves ${ }^{51}$ and those involving a transfer of shares in already existing concessionaires of areas, ${ }^{52}$ an unconventional production concession may be acquired through the ownership of (a) an exploration permit or (b) a conventional concession, without the need for bidding in either case. ${ }^{53}$ If this happens, the exploitation concessionaire, within the concession area, may require the subdivision of the existing area into new areas of unconventional hydrocarbon exploitation and the granting of a new Unconventional Exploitation Concession of Hydrocarbons. ${ }^{54}$ Likewise, holders of an unconventional production concession who are, in turn, holders of an adjacent and pre-existing conventional concession may request the unification of both areas as a single unconventional production concession, 'provided that the geological continuity of these areas is clearly demonstrated ${ }^{\prime 55}$

Exploration permits are granted for periods up to 11 years in respect of conventional onshore blocks and 13 years in the case of unconventional on-shore blocks. Periods are divided into three phases. In the case of exploration carried out in the Continental Shelf and territorial sea, each of the foregoing basic terms for exploration with conventional purpose may be increased by one additional year. Work commitments (including drilling commitments) are assumed in connection with each phase. Extensions for up to 5 years to be divided between the second and third phase are admissible. $^{56}$

\footnotetext{
50 art 45 FHL.

${ }^{51}$ The second paragraph of art 29 of the Hydrocarbons Law establishes '[ $t$ ] he Federal or Provincial Executive Branch, as the case may be, may [. . .] award exploitation concessions over proven zones to persons who comply with the requirements and the proceedings included in Part 5 [Awards] of this Title'.

52 The first paragraph of art 72 of the Hydrocarbons Law provides the following: 'Concessions and permits awarded pursuant to this law may be assigned, with the prior authorization of the Executive Branch, to such persons that that qualify and comply with the conditions and requirements established for the concessionaires or permit holders, as the case may be.'

${ }^{53}$ See art 27, para 2, of the Hydrocarbons Law, incorporated by art 4 of Law 27,007.

${ }^{54}$ See art 27 bis of the Hydrocarbons Law.

55 See ibid, second paragraph, of the Hydrocarbons Law.

${ }^{56}$ See art $23 \mathrm{FHL}$.
} 
Upon the expiration of each exploration phase (and completion of the respective exploratory commitments), the holder of the exploration permit may choose to either withdraw or pursue the next phase. However, to enter the next phase, the permit holder must relinquish 50 per cent of the remaining acreage covered by the permit. ${ }^{57}$ If the holder of an exploration permit discovers commercially exploitable quantities of oil or gas, the holder may apply for, and is entitled to receive, an exclusive concession for the production and the development of such oil and gas. ${ }^{58}$

A production concession vests in the holder the exclusive right to produce oil and gas, and take title to it at the well-head, from the area covered by the concession for a specific term for each type of concession (plus, in certain cases, a part of the unexpired portion of the underlying exploration permit), which may be extended. ${ }^{59} \mathrm{~A}$ production concession also entitles the holder to obtain a transportation concession for the oil and gas produced. ${ }^{60}$

Conventional exploitation concessions are subject to a 25 -year term, while unconventional exploitation concession last for 35 years-including a Pilot Period of up to 5 years, to be defined by the concessionaire and approved by the Enforcement Authority at the time of the initiation of the concession-and off-shore exploitation concessions are subject to a 30 -year period. ${ }^{61}$

In practice, the FHL divides the exploitation phase for unconventional hydrocarbons into two phases: first, a 'Pilot Period' that may not exceed 5 years, and second, a 'Development Period' that (in conjunction with the 'Pilot Period') may extend up to 35 years (plus any applicable extension). When the FHL defines 'Pilot Project' in its Article 27bis, it establishes that 'the purpose [of the "Pilot Project"] is to determine the commercial exploitation of the discovered field'. In other words, the Pilot Project is needed to confirm (or not) that full scale of the unconventional field is commercially

\footnotetext{
57 See art 26 FHL.

${ }^{58}$ See art $17 \mathrm{FHL}$.

${ }^{59}$ See art $35 \mathrm{FHL}$.

60 See art 28 FHL.

${ }^{61}$ See art 35 FHL.
} 
feasible. Thus, if the concessionaire decides to move to the development phase, it shall have to report to the Province the successful results of the Pilot Project.

Finally, Article 35 of the FHL allows holders of exploitation concessions to apply for and obtain multiple and unlimited 10-year extensions, provided that:

- They have complied with their obligations;

- They are producing hydrocarbons in the relevant block; and

- They submit an investment plan that is consistent with the development of the concession.

The relevant extension request must be submitted no later than one year prior to the expiration of the concession.

Pursuant to the $\mathrm{FHL}$, a 12 per cent royalty payment is required to be made in the jurisdiction in which the operations take place. ${ }^{62}$ Royalties are calculated on the proceeds from the sale of hydrocarbons (minus certain discounts reflecting a net-back to the well-head). Payments in kind may be negotiated with the respective province. Although payments of royalties are not computed because of taxes, they qualify as a deductible expense for income tax purposes. ${ }^{63}$ Upon each extension, the royalty rates will increase 3 per cent up to a maximum of 18 per cent.

\section{Midstream concessions}

If the Vaca Muerta shale oil and gas production is to benefit from the above regulatory regime with its special treatment of unconventional resources, it needs to address a different, non-legal problem: a bottle neck in existing capacity of gas and crude oil pipelines.

In Argentina, the development of pipelines to transport crude oil, natural gas liquids, condensate and other liquid by-products from production areas to market is governed by the FHL, while the development of natural gas pipelines is governed by the FHL and the Gas Law (GL).

The legal system conceives the hydrocarbons exploitation concessionaire (liquids and natural gas) (also referred as producer or operator) as the 'originator' (also referred as 'sponsor' or

\footnotetext{
${ }^{62} \mathrm{FHL}$, art 59.

${ }^{63}$ ibid art 56(c) VII.
} 
'initiator') of the legal title or license that grants the rights (i) to eminent domain to condemn a right of way easement along the proposed route, (ii) to build, operate and maintain the pipeline, and (iii) to transport its production up to the market or connection with a main trunk pipeline; for a period equivalent to the term of their exploitation concessions ( 25 or 35 years depending on the nature of the concession-conventional or unconventional hydrocarbons-, plus potential multiple 10-year extensions).

This means that except as described below, an exploitation concessionaire is the only entity entitled to request (and obtain) a 'transportation concession'. It is also the only entity entitled to a preferential right over the pipeline's capacity to transport its own hydrocarbons (liquid and gas) production, being forced to grant open access to third parties exclusively in respect of any vacant capacity. In any case, a transportation concessionaire servicing third parties may only charge a regulated tariff established by the State.

An independent midstream company may not request (and obtain) a transportation concession, except for two alternatives: (i) winning a public auction in which the State awards a transportation concession over a specific route (eg the case of the Oldelval pipeline), or (ii) acquiring the transportation concession from the exploitation concessionaire by way of an assignment agreement duly approved by the State (eg the case of the Pacifico pipeline or the Atacama pipeline). In both cases, the midstream company shall charge its customers a regulated tariff. Furthermore, in these situations the midstream company will not enjoy the preferential right that the originatorexploitation concessionaire held at the inception.

However, if, even under those arrangements, midstream companies are willing to invest in liquid pipelines, they face a development obstacle. Currently, liquid pipelines operate under a 'common carrier' system (relatively like the US system that is governed by the Interstate Commerce Act). Except for the preferential right of the originator-exploitation concessionaires-for transporting its own production, transportation concessionaires must provide a transportation 
service to any party that reasonably requests service. This means that if a pipeline is constrained and a new customer asks for transportation service, the oil pipeline's capacity must be allocated among its customers-including the new customer-and the existing customers all lose some of the capacity they otherwise would have had.

In contrast, on a gas pipeline, service is provided to customers on a 'contract carriage' basis that entitles customers to firm capacity on the pipeline (relatively similar than the US system governed by the Natural Gas Act). If a new customer requests service on a constrained gas pipeline, the pipeline would not be required to provide service to the new customer. Firm contracts are assigned through an Open Season mechanism governed by the GL and stewarded by the ENARGAS.

In an approach that contrasts with the US, the State does not require the pipeline to reserve some portion of its capacity for allocation among spot or 'walk-up' shippers, but instead authorizes that 100 per cent of capacity be allocated to committed or contract shippers. Officials at the Ministry of Energy and Mining have publicly stated that a new regulation establishing a 'contract carriage' system for liquid hydrocarbon pipelines coupled with an Open Season mechanism will be issued during 2018. If this reform is introduced, it would be well received by the oil and gas sector. 'Without it, project sponsors lack certainty as to the revenue they will be able to generate once the pipeline is completed, as well as the service terms that the pipeline will be required to offer.'

\section{Challenges and locally crafted solutions}

\section{Foreign influence}

In contrast to the US shale revolution in which the US-based independents led the quest, the corporate pioneers in Vaca Muerta were foreign-owned companies, and usually the largest internationally operating ones. They also have the leading role on the legal expertise required to carry out such a sophisticated project. In July 2017, a joint venture formed by Total, Wintershall, Pan American Energy (PAE) and YPF (the state hydrocarbons company) signed a multi-project package deal that commits, in aggregate, more than one billion dollars to be invested in three different blocks: Aguada de Castro, Aguada Pichana Este and Aguada Pichana Oeste. 
The transaction was innovative in several ways:

- Block split: the parties originally held interests in a historical gas field awarded during the early 1990s called Aguada Pichana of approximately 338,000 acres. The parties, under Total's operatorship, had mainly developed the eastern side of the block with conventional and tight gas projects. To maximize investment and acreage development, the parties subdivided the block in two (Aguada Pichana Oeste and Aguada Pichana Este). Total continued as operator of the east (approximately 188,000), while PAE became operator of the west (approximately 150,000 acres).

- Horizontal severance: In Aguada Pichana Este, given that the joint venture had already derisked the conventional and tight prospects, the parties agreed a horizontal severance of the block. While the conventional and tight gas prospects continue under the existing participating interests, the parties will have different interests in the new shale prospects.

- Equity swaps: the parties, in different proportions, had interests in two blocks (Aguada de Castro and Aguada Pichana) that were converted in three blocks due to the subdivision of the former and, de-facto into four blocks, given the horizontal severance of Aguada Pichana Este.

- Infrastructure usage: with the aim of reducing development costs of non-de-risked fields such as Aguada de Castro and Aguada Pichana Oeste and taking advantage of infrastructure existing capacity in Aguada Pichana Este, the parties agreed the use of the facilities existing in Aguada Pichana Este by the parties developing the Aguada de Castro and Aguada Pichana Oeste.

\section{Local content}

Local content within the oil and gas industry is generally recognized as a form of intervention by government that has the aim of ensuring that most of the goods and services required at each stage of the oil and gas value chain are locally supplied. In Argentina there is a 'Purchase Vaca Muerta' (Compre Vaca Muerta), a local content policy designed by the Province of Neuque'n that requires exploration and production (E\&P) companies and major service companies with activity in Neuque'n to prioritize local suppliers with the aim of boosting local supply chain development.

The 'Purchase Neuquino', sets out a local content policy that will accompany the industry's growth. The legal framework for this is composed by: (i) Provincial Law 2755 dated 14 December 2010 ('Law 2, 755' $)^{64}$; (ii) Supplementary Decree 2379 dated 28 December 2012 ('Decree 2, 379') 65;

\footnotetext{
${ }^{64}$ See text in Spanish at <http://cvh.cpymeadeneu.com.ar/marcoLegal.php> accessed 12 July 2018.

${ }^{65}$ See text in Spanish at <http://cvh.cpymeadeneu.com.ar/pdf/D_2379_2012.PDF> accessed 12 July 2018.
} 
and (iii) the 'Proceeding for the Monitoring and Control of Procurement under Law 2, 755' dated 1 June 2014 (the 'Proceeding'). ${ }^{66}$

Enforcement authority. The Enforcement Authority of the 'Purchase Neuquino' is the Centro PyMEADENEU, ${ }^{67}$ which stands for Centre for Small and Medium-sized Enterprises-Agency for the Economic Development of Neuquén (Centro de la Pequeña y Mediana Empresa-Agencia de Desarrollo Económico del Neuquén). The Director is Mr Facundo Lopez Raggi. ${ }^{68} \mathrm{~A}$ key question in the near term-and not one that can be answered yet-will be the effectiveness of this body given the ambition in the policy itself.

Preference for local suppliers. E\&P and major service companies must give preference to local suppliers ('Empresas Neuquinas') when procuring goods and services ${ }^{69}$ Such preference must be granted to local suppliers ('Empresas Neuquinas') when their price is lower, equal or a 7 per cent higher than the price offered by a non-local supplier, in respect of identical or similar good or service. $^{70}$

Such preference is only applicable to a 60 per cent of the 'total contracted amount for each category or activity'. ${ }^{71}$ For instance, if US\$100,000 were allocated to transportation services, a 60 per cent of such amount would be subject to the 'priority' established in the 'Purchase Neuquino', while the remaining 40 per cent would be freely allocated to non-local suppliers.

\footnotetext{
${ }^{66}$ See text in Spanish at <http://cvh.cpymeadeneu.com.ar/app/?page=Operadora.Login> accessed 12 July 2018.

${ }^{67}$ See $s 11$ of Law 2755.

${ }^{68}$ See website at <http://cvh.cpymeadeneu.com.ar/index.php> accessed 12 July 2018.

${ }^{69}$ See $s 1$ of Law 2755. See also s 1 of Decree 2379 that clarifies that the service companies included in the 'Purchase Neuquino' are those 'contractors directly retained' by E\&P companies (such as Halliburton, Schlumberger, Weatherford, etc.), thus excluding any subcontractors.

${ }^{70}$ See $s 9$ of Law 2755.

${ }^{71}$ This is the official criterion of the Enforcement Authority for assessing the fulfilment of the mandatory $60 \%$ (see s 4.3.2., para 1, when it states that 'el monitoreo y seguimiento de la aplicación de las prioridades de contratación se efectuará sobre el total del monto contratado para cada uno de los rubros o tipo de actividades requeridas'). However, it is worth noting that, when determining the base for assessing the fulfilment of the mandatory 60\%, s 8 of Law 2755 refers to the 'totality of the contracted services and goods' (in Spanish: 'Este sesenta por ciento (60\%) sera tomado del total de los servicios o bienes por los cuales se contrata').
} 
The Enforcement Authority has published a chart to exemplify the method it will use for assessing the mandatory 60 per cent: ${ }^{72}$
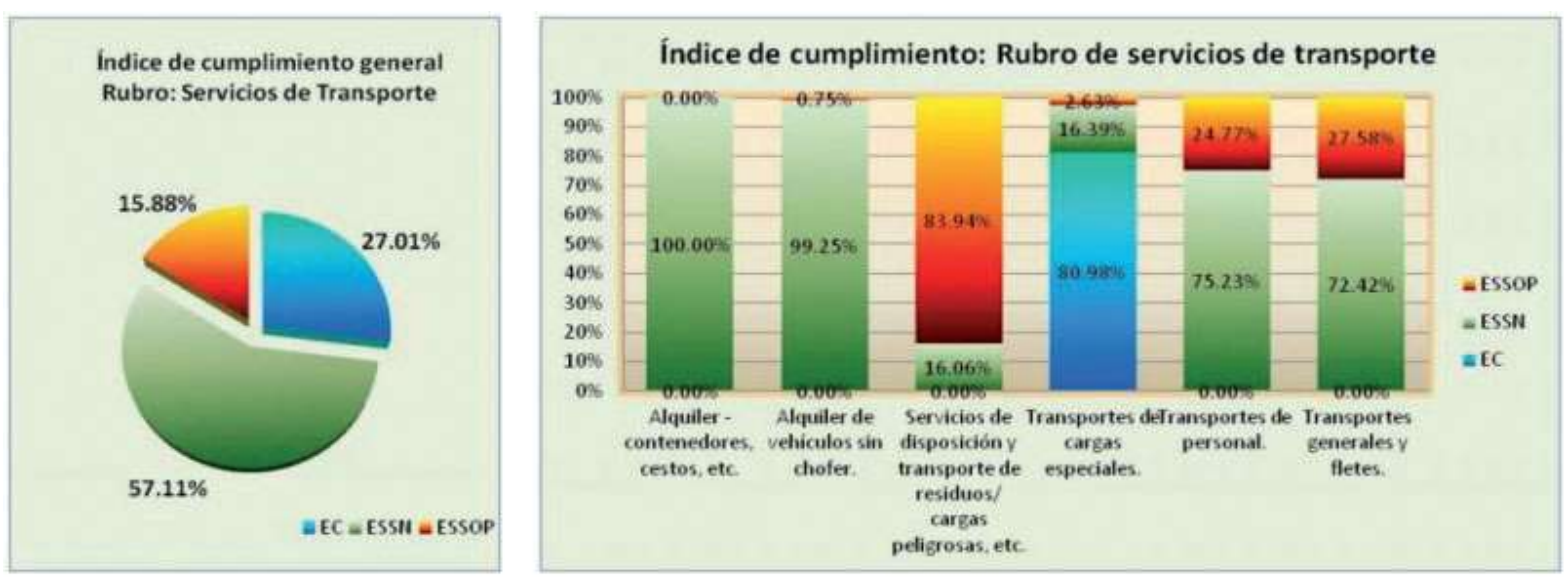

\section{Referencias:}

\section{EC: Empresa Certificada Neuquina}

\section{ESSN: Empresa con Sede Social en la Provincia del Neuquén}

ESSOP: Empresa con Sede Social en otra Provincia

If the service or good to be contracted, hired or purchased is indivisible, the priority shall be of 100 per cent. ${ }^{73}$ If it were to be possible, due to the nature and purpose of the relevant good or service, the agreement executed with the local supplier ('Empresa Neuquina') must be in effect for at least one year. ${ }^{74}$ The Enforcement Authority shall assess the fulfilment of the mandatory 60 per cent on the basis of yearly periods beginning on 1 January and ending on 31 December of each year. $^{75}$

Categories. The Enforcement Authority has included the following categories within the 'Purchase Neuquino': ${ }^{76}$

1. Oil Services on the field;

2. Civil Engineering and Works;

3. Electro-mechanic Engineering and Works;

\footnotetext{
72 This chart was published at page 7 of the Proceeding, accessed at the following website: $<$ http://cvh.cpymeadeneu.com.ar/app/upload/operadora/PG_CPYME_PHC_02_Monitoreo_de_aplicacion_Op eradoras_y_Servicios_C_Rev_00.pdf> accessed 12 July 2018. The term 'ESSN' stands for a local supplier that it is in the process of obtaining the certificate of 'empresa neuquina'.

${ }^{73}$ See $s 8$ of Decree 2379.

${ }^{74}$ See s 10 of Law 2755 . See also s 10 of Decree 2379.

${ }^{75}$ See s 4.4 .1 of the Proceeding.

${ }^{76}$ See s 4.2 of the Proceeding.
} 
4. Transportation Services;

5. Metal-mechanic Engineering, Works and Goods;

6. IT and communications;

7. Maintenance of service stations;

8. Environmental services;

9. Consulting services; and

10. Other services.

Excluded goods and services. Due to a lack of their availability in the Province of Neuquén, the

Enforcement Authority has excluded the following goods and services from the 'Purchase

Neuquino': ${ }^{77}$

Category (1): Oil Services on the field

- Seismic services

- Underbalance drilling services

- Well-head services

- Cementing services

- Cementing and stimulation services

- Coiled tubing services

- Services with automatic drilling equipment

- Services with drilling rigs

- Work-over services

- Stimulation services

- Supply of drilling/completion fluids

- Supply of special products on field (chemicals, proppants, sand, cementing products, etc.) (to be assessed depending on the product)

- Treatment of waste

- Well logging and casing services

- Directional drilling services

- Heat tracing services

- Top drive services

Category (3): Electro-mechanic Engineering and Works

- Maintenance of power generators

- Maintenance of real-time operating systems (RTOS)

- Operating and maintenance of gas plants

Category (4): Transportation Services

- Air transportation

Category (5): Metal-mechanic Engineering, Works and Goods

- Repair service of turbo-compressors (to be assessed on a case-by-case basis)

- Maintenance and repair of valves (to be assessed on a case-by-case basis)

- Operation and maintenance of pumping stations

Category (10): Other Services

${ }^{77}$ See s 4.3.2.1 of the Proceeding. 
- Supply of satellite television

- Supply of grid power

- Supply of gas compression services.

The budget allocated by E\&P and large service companies to the excluded goods and services does not count for purposes of assessing the mandatory 60 per cent. ${ }^{78}$ For instance, if the budget for E\&P is US\$50 million and US\$45 million are allocated to the excluded goods and services, only the remaining US\$5 million allocated to goods and services included in the 'Purchase Neuquino' will count for assessing the mandatory 60 per cent. Therefore, US\$3 million should be allocated to local suppliers.

Beneficiaries ('Empresas Neuquinas'). The 'Purchase Neuquino' benefits local suppliers (individuals or legal entities) who complied with certain requirements to qualify as an 'empresa neuquina', including: ${ }^{79}$

- The domicile and main seat of business must be located in the Province of Neuquén for 5 years before the enactment of Law 2755 (i.e. December 2005).

- A 70 per cent of the capital stock must be owned by individuals or legal entities domiciled or registered in Neuquén. In the case of joint ventures, a 70 per cent of it must be controlled by a local supplier.

Any local company directly or indirectly controlled by national or foreign companies will not qualify as a local supplier ('empresa neuquina'). ${ }^{80}$ To enjoy the benefits of the 'Purchase Neuquino', local suppliers must submit before E\&P companies and major service companies a certificate issued by the Enforcement Authority that expressly qualifies the local supplier as an 'empresa neuquina'. Such certificate must be renewed on a yearly basis. ${ }^{81}$

Reporting obligations. The Enforcement Authority may request to the E\&P companies and major service companies' information and documentation, or conduct audits, regarding their fulfilment of the 'Purchase Neuquino' ${ }^{82}$ E\&P companies and major service companies must report to the

\footnotetext{
78 See s 4.4 of the Proceeding.

${ }^{79}$ See s 5 of Law 2755. See also s 5 of Decree 2379.

80 See $s$ of Law 2755. See also s 6 of Decree 2379.

${ }^{81}$ See s 7 of Law 2755. See also s 7 of Decree 2379.

82 See s 12 of Decree 2379. See also s 4.4 .1 of the Proceeding.
} 
Enforcement Authority any call for bids for the award of a contract, work or service. The Enforcement Authority may publish those calls for bids in its website. ${ }^{83}$

Penalties. Any company not complying with a requirement of the Enforcement Authority shall be warned. If the breach is not cured, the Enforcement Authority may establish a fine ranging from US\$7000 and US\$60,000, upon conducting an administrative proceeding that guarantees the right of defence of the company. ${ }^{84}$ If the company does not reach the mandatory 60 per cent, it may submit before the Enforcement Authority a plan detailing the objectives and points of action to be implemented in order to fulfil with the 'Purchase Neuquino' ${ }^{85}$

\section{Assessment}

To replicate at least some of the US shale experience in Argentina, the case study demonstrates that specific legal instruments have been introduced, especially in the concession arrangements but also in terms of the ambitious and highly detailed local content policy, clearly aimed at building up a services sector. The location of the main shale plays away from densely populated areas is no doubt a factor in their rapid development to date. The 'social licence to operate' has not been a major concern in these areas. Building on its promising geology, Argentina has made considerable effort in its recent law and policy to provide credible legal and economic stability to investors. The plethora of instruments and incentives provides an encouraging setting for investment promotion, leading to a future reversal of the decline in oil and gas production and a recovery of Argentina's energy independence.

\footnotetext{
${ }^{83}$ See $s 16$ of Law 2755.

${ }^{84}$ See $s 19$ of Law 2755 . See also s 19 of Decree 2379.

${ }^{85}$ See $\mathrm{s} 4.6$ of the Proceeding.
} 


\section{CASE STUDY 2: COLOMBIA}

\section{Reacting to shale 1.0}

The development of the unconventional hydrocarbons industry in the US, and its success in terms of the rapid increase of production that allowed it to become self-sufficient after decades of being a net importer, attracted considerable attention in Colombia.

Evidence of suitable geology and possible reserves was already there. According to the US Energy Information Administration, the Colombian territory holds two formations (La Luna and Guacheta') that share features and other similarities with the Eagle Ford shale play in Texas, ${ }^{86}$ one of the most productive formations of unconventional hydrocarbons in the USA. ${ }^{87}$

Estimated reserves of Colombia are around 55 Trillion Cubic Feet (TCF) of shale gas and 6.8 billion barrels of shale oil, located in the areas with better potential for the development of shale gas and oil resources. To stimulate interest in shale resources, a bid round was held in $2012^{88}$ in which the government offered 12 areas located over plays with new prospectivity, and 18 areas on frontier plays where the geological knowledge was very limited. The result was the licensing of five areas of the former, but none of the later. In addition, the government included a tax incentive for unconventional hydrocarbons, under which the royalty to be paid over the production of unconventional resources is only 60 per cent of the rate for conventional oil production. ${ }^{89}$ This round signalled the beginning of government actions to promote unconventional hydrocarbons resources.

\section{The legal and policy framework}

Under Article 332 of the Constitution, ownership of the subsoil and all non-renewable natural resources lies with the State. Under certain conditions, private parties may explore for and produce

\footnotetext{
${ }^{86}$ US Energy Information Administration. Technically Recoverable Shale Oil and Shale Gas Resources: An Assessment of 137 Shale Formations in 41 Countries Outside of the US. US Department of Energy. Junes 2013. 87 US Energy Information Administration. Drilling Productivity Report for key tight oil and gas regions. March 2015.

${ }^{88}$ NHA. Term of reference for Colombia Round 2012. <http://www.anh.gov.co/Asignacion-deareas/Procedimientos-deSeleccion/Procesos\%20Anteriores/Ronda\%20Colombia\%202012/Terms\%20of\%20Reference\%20Addendum\%20No.\%204\%20English\%20translation.pdf> accessed 1 March 2018.

${ }^{89}$ Law 1530 of 2012. art 14.
} 
hydrocarbons however, subject to grant of rights in the form of a concession and payment of royalties. The rules for hydrocarbons activities are set out in national laws, regulations and in the terms of concessions granted to applicants from time to time.

A hydrocarbons policy emerged in the 1990 s as a response to instability in the country's energy supply. Due to the El Niño phenomenon, the supply of electricity was adversely affected by a drought that left the country with constant blackouts for almost a year. ${ }^{90}$ This drew attention to the fundamental role that energy played in the daily functioning of the country, and as a driver of its future development. At the time, Colombia was heavily dependent upon hydroelectric power (in 1992 it amounted to 78 per cent of the installed capacity), and given the risks associated with such supply and climate-related events this put the country in a very risky position. ${ }^{91}$ Among other measures taken by the government to lessen this risk, the diversification of primary energy sources led to the investment and development of fossil fuel-powered generation plants. Ironically, while Colombia is one of the largest exporters of coal, most of the plants built for this purpose used gas as the source of electricity generation.

This situation provided an impetus to the identification of indigenous supplies of oil and gas, which eventually led to important discoveries during the 1990s that in turn allowed a constant supply of petroleum. This covered the local demand for gas and increased the resources of the government through revenues from oil exports. ${ }^{92}$ In 2006 the government issued a national energy policy document (National Energy Plan $2006-25^{93}$ ), in which it stated the need to continue the process of diversification of primary energy sources. This included the need to increase the rate of exploration drilling, as well as the potential need to build a regasification terminal on the coast.

\footnotetext{
${ }^{90}$ AC Mateus, 'Energy Crisis in Colombia' (2016) 4(2) Tecnología, investigación y Academia.

${ }^{91}$ UPME. Study to determine the vulnerability and adaptation option of the Colombian energy sector to face climate change, December 2013, p 68.

92 UPME. Boletín Estadístico de Minas y Energía, 2005, pp 22 and 30.

93 UPME. Plan Energético Nacional, 2006-2025, 2006.
} 
Energy security was the dominant concern and increasing the supply of hydrocarbons was a key element in ensuring energy security.

These measures have ensured a diversification of the energy matrix. By 2012, 69.9 per cent of the electricity in Colombia was generated by hydro-powered sources, 24.8 per cent by gaspowered sources, and 4.9 per cent by coal-powered sources. ${ }^{94}$ However, there was still a need to develop additional supply sources of hydrocarbons to continue supporting the economy, in case of a recurrence of extreme climate patterns such as the deterioration attributable to the El Niño phenomenon.

Nonetheless, the hydrocarbons reserves bear no comparison with those of its neighbour, Venezuela. Hydrocarbons have become a part of the Colombian economy but are not central to it. Foreign companies have long been present, and several contractual systems have been applied, including the service contract as early as 1951, and later an association contract until 2003. ${ }^{95}$

At the beginning of the 2000s, the hydrocarbons sector was in decline and needed a dramatic restructuring if it was to survive. As of 1999, the estimated reserves of hydrocarbons appeared likely to supply the needs of the economy for the next four years, and the number of exploratory wells was a mere 10 in the year 2002; despite this, the government take was as high as 82 per cent. ${ }^{96}$ Changes implemented by the government included the partial privatization of the National Oil Company (NOC) (10 per cent of its shares), the transfer of regulatory capacity to an independent regulatory body (the National Hydrocarbons Agency, or NHA), as well as a substantial reduction in the government take. By implementing law-decree 1760 of 2003, the government separated out the activities of the NOC (also known as Ecopetrol). It focused Ecopetrol's operations on exploration and production, while passing regulatory powers to the NHA. In addition, the

\footnotetext{
${ }^{94}$ UPME. Study of electricity generation under a scenario of climate change. 2012.

${ }^{95} \mathrm{G}$ Perry and M Olivera, El Petróleo en la Economía Colombiana. Petróleo >bendición o maldición? 2012. p 176.

${ }^{96}$ ibid p 181.
} 
contractual system changed from an association contract to a modern concession system. Two primary types of concession contract were used: a Technical Evaluation Agreement was created to incentivize the investor to carry out exploration activities, and an Exploration and Production Contract was created to incentivize the final exploration and a more concrete phase of hydrocarbon production. ${ }^{97}$

Under this new concession model, the participation of the government or the NOC was limited to its regulatory role. They therefore did not participate in any exploration or commercial decision-making. In addition, this new model entitled the investor to the full rights of production, after the payment of tax and royalties..$^{98}$

The results of the implementation of the abovementioned changes had a direct impact on the oil and gas sector in Colombia. Exploratory activity increased, and in 2003 alone there were 28 new A3 wells drilled - five of them with successful results. In addition, seismic exploration also increased to $3470 \mathrm{~km}$ in the same year. ${ }^{99}$

Regulatory stimuli and favourable international prices thus combined to power the hydrocarbons sector in Colombia. After 2003, companies from Europe, North America and Asia decided to invest in the prospects offered by the government. Due to the increased investments and the continuous efforts from the private and public sectors, production of oil in Colombia increased from 528 thousand barrels a day in 2004 to 786 thousand a day in 2010. At the peak point of production in 2013 , over one million barrels per day were produced. ${ }^{100}$

The improvement in production also reflected a sustained increase in foreign direct investment, as the oil and gas sector jumped from USD 278 million in foreign direct investment in

\footnotetext{
97 NHA. Agreement 008 of 2004.

98 UPME. La Cadena del Petro'leo en Colombia, 2005, p 28.

99 ibid p 30.

100 PWC. Colombia Oil \& Gas Industry 2014. 2014.
} 
2003 to over USD 5.4 billion in $2012 .{ }^{101}$ Additionally, the income of royalties received by the Colombian government between 2010 and 2014 had an increase of 40 per cent, demonstrating a correlation between the progress of the energy sector and the additional sources of funding for the government. ${ }^{102}$

However, the boom in commodity prices, especially with respect to hydrocarbons, began slowing down in 2014. The oil and gas industry in Colombia was faced with the need to restructure to maintain the levels of production and exploration. The answer came from the independent regulatory body, the NHA, which became more flexible with respect to contractual deadlines, among other measures. The NHA also allowed the option of transferring investment commitments from certain exploration programmes to others that were on the license, or to other licenses granted to the same company. ${ }^{103}$

This situation affected the finances of the Colombian government, which decided to carry out a tax reform to compensate for the decline in revenues it was receiving from oil and gas production. ${ }^{104}$ Despite the abovementioned measures taken by the Colombian government to maintain levels of production, sustain the rate of foreign investment and stabilize the conditions of the market, the fall in the price of oil affected the industry negatively and its activity began to decline. According to a report from a fiscal agency within the Colombian government, the lack of exploration and the low price of hydrocarbons indicated that the country could become a net importer of oil as early as $2021 .{ }^{105}$

\footnotetext{
${ }^{101}$ Colombian Central Bank. Statistics on Fluctuations of Foreign Direct Investment per Sector. <http://www.banrep.gov.co/es/inversiondirecta> accessed 1 March 2018.

${ }^{102}$ Natural Resource Governance Institute. Los Efectos del Boom de las industrias Extractivas en los Indicadores Sociales en Colombia.August 2016.

${ }^{103}$ NHA. Agreement No 02 of the 16th of March 2015.

104 Justification of Tax Reform 2016.

<https://www2.deloitte.com/content/dam/Deloitte/co/Documents/tax/Exposicio'n\%20de\%20Motivos\%20Ref orma\%20Estructural\%202016.pdf> accessed 1 March 2018.

${ }^{105}$ Contraloría General de la República. Autosuficiencia petrolera en Colombia. Macro-Sectorial Bulletin No 6 . May 2017.
} 
Ecopetrol (the NOC) has had success in several areas of exploration, but the rate of these findings is not sufficiently high to compensate for the replacement of reserves. This replacement of reserves is needed for Colombia to regain control over its own security of supply on hydrocarbons. As a result, the policy choice of encouraging exploration of unconventional hydrocarbons gained traction. A debate began about whether such oil and gas formations should be developed or not. For some, shale resources appeared to be one attractive way of tackling the issues outlined above.

\section{Regulating to promote unconventional hydrocarbons}

The National Council for Social and Economic Policy is the highest authority for policy decisions in Colombia. In 2008, it issued a document where it recommended establishing technical guidelines for the exploration and production of unconventional hydrocarbons. It also recommended the design of legal tools and a model contract that could be utilized when taking decisions based on the technical guidelines. ${ }^{106}$ This document was the first public document that the Colombian Government issued regarding shale resources, and it was the first official sign of an intention to develop them.

In 2012, the Ministry of Mines and Energy issued a resolution where it established the procedures for the exploration and production of unconventional hydrocarbons. The resolution referred to the first technical requirements for exploration, such as seismic information, the decommissioning of exploratory wells, and requirements to commence a production well. Additionally, the resolution includes a procedure to be utilized if two lawful license-holders, who have the right to explore and exploit the natural resources underground, have interests in the same areas and face a conflict on who can exploit the resource. According to the Colombian government, it is required that the parties begin a negotiation and each present action plans to solve the conflict, as well as provide a technical basis for a better exploitation of the underground resources. If no agreement is reached by the parties, the Ministry of Mines and Energy will appoint an expert (from a

\footnotetext{
${ }^{106}$ Document CONPES 3517 of 12 May 2008
} 
group of experts nominated by the parties) who will decide from a technical perspective which party has the best possibility of optimizing the exploitation of the resources. ${ }^{107}$ This unique situation provides a way to solve, for example, a conflict between a titleholder for a coalmine that is in the production phase, and a potential license holder that may be interested in exploiting Coalbed Methane reserves that are in the same area.

In 2014, several technical and contractual developments occurred that improved the prospects of the unconventional hydrocarbons industry in Colombia. The NHA produced a model Exploration and Production contract that included modifications reflecting the particularities of unconventional hydrocarbon resources. For example, the exploration period was extended from 6 to 9 years, the period for the programme of evaluation was extended from 2 to 4 years, and the production period was extended from 24 to 30 years. Regarding the relinquishment of land, it allowed the licensee the right to maintain 50 per cent of the areas that have been assigned under the license if they present a new exploratory programme. ${ }^{108}$

The contractual process was also modified, and the financial and technical requirements for the development of unconventional hydrocarbons were raised according to the type of activity and the area that would be explored. In general, all requirements were stricter for the concessionaire than those applicable to a conventional hydrocarbons project. ${ }^{109}$

In the same year, the Ministry of Mines and Energy issued special regulations for the exploration and production of unconventional hydrocarbons. This new directive was very detailed with respect to the procedures and technical specifications for the construction of wells, particularly in the areas where underground water sources may be located. ${ }^{110}$

The regulations covered the areas illustrated in Table 2:

\footnotetext{
${ }^{107}$ Ministry of Mines Resolution 180742 of 2012.

108 Brigard \& Urrutia. Boletin Legal. 19 edn, 2014.

109 NHA.Agreement 03, March 2014.

${ }^{110}$ Ministry of Mines. Resolution 90341 of March 2014.
} 
The abovementioned regulations refer to key issues that have been at the heart of the technical controversy over shale gas in the USA and can be seen as providing a basis to respond positively to environmental concerns about the production of shale resources.

In the same year-2014-the Ministry of Environment issued the terms of reference for the environmental impact assessment for unconventional hydrocarbons, ${ }^{111}$ with very specific requirements addressing the new situations and potential risks that the new techniques could bring. Amongst them were:

- The need to include studies about the underground water sources, its geological features, direction of the flow of water, connection with other aquifers, and condition for human consumption of the liquid.

- The need to inform the authorities about the location of aquifers, permeability of the stratigraphic formations, including any faults or fractures that are present.

- It is required to prepare a baseline study on quality of air, including the monitoring and presence of carbon monoxide, methane, among others.

- The need to disclose the products that will be used on the fracturing liquid, including the name of the chemical product as it is known in the market, and its purpose on the fluid in the chemical substance is under any recognized trade secret, the chemical general family must be included.

\section{Challenges and locally crafted solutions}

\section{Foreign influence in the regulatory developments in Colombia}

By 2012 the authorities had decided to consider the potential risks and benefits of developing unconventional hydrocarbons in Colombia in greater detail, considering experiences from other countries with more technical knowledge, as well as international bodies such as the Commission of the European Union. On an informed basis, it then proposed to take a decision to support this innovative technology and its use in Colombia or not.

The study was divided into four phases: (i) consultation and advice from renowned international experts; (ii) field visits from the highest authorities to the blocks and areas where shale gas had been developing; (iii) meetings with regulators and technical authorities of the countries and

${ }^{111}$ Ministry of Environment of Colombia. Resolution 0421 of 20 March 2014. 
states that have allowed the technology to be used in their areas, and next, (iv) a final decision would be taken.

The first phase included the invitation of experts that had been advising the American government on fracking and its development. These experts advised the personnel of the four institutions that would potentially be involved in the regulation of any activity related to fracking. ${ }^{112}$ Fourteen different experts, with both positive and negative views on the use of fracking, were invited to share their knowledge and opinions with the staff of the authorities. This process was designed to allow the decision-makers, their support staff, and particularly the people that would have to deal with the events on a day-to-day basis, to have a better understanding of the technology, the risks and the benefits that fracking could bring.

The second phase included the visit of officers from the Ministry of Mines and Energy and the Ministry of Environment to British Columbia and to Texas, principally to the zone where the Eagle Ford formation is located. This allowed them to see and experience at first hand the development and activity that was carried on there, and to evaluate the reality of a production area.

The visits also coincided with several meetings with regulatory bodies from Colorado, Texas, Pennsylvania, Alberta and British Columbia. These meetings helped the officers to understand from a technical point of view, ${ }^{113}$ drawing upon the experience of those states and provinces, how the industry had developed, how the regulations were able to reduce risks, and how the operations had been carried out in those areas. ${ }^{114}$

The result was that these efforts produced the technical regulations for the exploration and production of unconventional hydrocarbons, the terms of reference for the environmental impact

\footnotetext{
${ }^{112}$ The institutions are: The Ministry of Mines and Energy, The Ministry of Environment, The National Hydrocarbons Regulator and the Authority on Environmental Licenses.

${ }^{113}$ The Colombian Government also attempted to contact the French authorities to understand their reticence about fracking. However, there was no response, and the French experience and point of view was not heard by the Colombian government.

${ }^{114}$ A Bermúdez, Así nació la hoja de ruta para el fracking. Lasillavacia.com. September 2014.
} 
assessments required for the environmental licenses, and the modification of the standard concession contract that allows for exploration and production of oil and gas in the country.

The comparative aspect of the study, drawing upon experiences and advice from regulators and policy experts from countries and areas where the boom has occurred, were essential in developing the regulatory framework in Colombia. Extrapolating from the experiences of the US, the need for baseline studies on the geology of the area, the location of aquifers and the potential for tremors and seismic activity became clear. This information is now required by the Colombian authorities-an example of how the regulatory processes from other jurisdictions has influenced the substantive regulatory process in Colombia.

Another example of how North American experiences have shaped the regulatory process in Colombia is the increase in financial and technical requirements for companies that are interested in developing unconventional resources. Experience in the US and Canada has shown the need for profound technical knowledge, skill and capacity to manage the complex requirements of fracking and horizontal drilling. It is also necessary to have substantial financial capacity to fund such a capital- and time-intensive operation, and especially to be able to demonstrate this capacity in the event of unforeseen issues. Therefore, the increases in requirements show how the Colombian authorities have learnt from foreign experiences and used this knowledge in crafting their own regulations.

\section{Overlapping claims}

Concern about overlapping locations of interest between conventional and unconventional hydrocarbons licensees seems to be a constant feature of the Colombian framework. ${ }^{115}$ The current regulations provide different options for companies that may find themselves in this position.

\footnotetext{
${ }^{115}$ For a comprehensive discussion of this subject see the LLM Thesis by Jorge E Arango Camacho, 'Colombian Legislation on Unconventional Hydrocarbons' University of Dundee (2015).
} 
On the one hand, the abovementioned procedure for the solution of disputes between licensees with a conflict regarding who may develop a specific hydrocarbon or mineral resource and how to develop it appears to be a new stage in the regulation of shale resources. However, the regulation also allows another option, where the holder of an unconventional licence is encouraged to create a team or consortium with a licensee that already has conventional resources under development. With this approach, a new company could develop the area for the conventional resources in place as well as for unconventional resources that may also be there. This approach clearly makes effective use of the infrastructure currently in place, which may have already been developed with the local community and have the technical features and information already obtained by the previous licensee on the ground.

While conflicting interests in areas of exploration are evidently a persistent feature of hydrocarbons activity in Colombia, the regulators have been able to create pathways to develop both conventional and unconventional resources-both of which are useful to improve the security of supply for the country.

\section{Assessment}

The hydrocarbons industry plays a key role in the economy of Colombia, due to the large foreign investment it attracts and the income it generates for the government of a developing country. However, as this country study demonstrates, extensive measures have been taken to adapt it to changed circumstances, notably in 2003 and again to introduce a regime for unconventional hydrocarbons development. The latter contains several features of note: a distinct regulatory regime, and wide-ranging public consultations on its design; steps to ensure that conventional and unconventional activity is harmonized from a regulatory point of view. An interesting gap is that local content requirements appear to be absent from the Colombian regime for shale gas resources, and no distinct local content policy is evident. 
If one looks beyond the hydrocarbons sector, there are three macroeconomic or social factors that are likely to influence the future development of shale resources. Firstly, while Colombia has made substantial progress in the peaceful solution of its internal armed conflict by signing a peace agreement with a body known as the Revolutionary Armed Forces of Colombia (in Spanish the acronym is FARC), other guerrilla groups continue to engage in terrorist activity and target the vulnerable hydrocarbons transport infrastructure. Secondly, local communities have begun to mobilize themselves to oppose projects involving the extractive industries (particularly mining projects), using electoral tools that may allow them to legally prohibit extracting activities on their land, adding doubt to investors seeking a social license to operate on Colombian territory. Finally, the economic and financial viability of petroleum production is challenged due to high lifting and transportation costs.

However, the possibility that Colombia may in the foreseeable future have to commence imports of hydrocarbons from its neighbours or from other countries is an option that many policymakers and private sector leaders see as 'of last resort'. Therefore, there seems to be a consensus emerging for the need to make a renewed effort at developing unconventional hydrocarbons. The need to increase the reserves, and to replace the income for the central government, seems to be driving informed opinion towards the development of shale resources. Nevertheless, there is strong opposition from a different (and still informed) constellation of environmental groups, local communities and academics. This is likely to require a new policy initiative from government to move forward.

\section{CASE STUDY 3: UK}

\section{Reacting to shale 1.0}

The emergence of an unconventional hydrocarbon industry was kick-started in the UK by the interest of policy-makers in the rapid development of unconventional resources across the Atlantic and the evident economic benefits this brought to the US economy. For some in the UK, this seemed to be a 'game-changer', occurring fortuitously at a time when the UK's revenues from North Sea oil 
and gas were in decline and import dependency was on the rise. In 2016, only 43 per cent of UK gas requirements were met from UK production and 57 per cent were imported from outside the UK44 per cent from European pipelines and 13 per cent from LNG tankers. In other words, the UK imports more gas than it produces, and by the start of 2017 gas production was no more than a third of the peak level recorded in $2000 .{ }^{116}$

The speed with which Shale 1.0 appeared to transform the US energy economy acted as a stimulus to UK policy development with the goal of replicating the US success even if on a smaller scale. In this Case Study we examine how the existing regulatory regime for conventional hydrocarbons was initially modified, and then supplemented by a series of specific legal measures aimed at promoting unconventional resource exploration and development.

An initial lack of knowledge of the geological potential was boosted by several studies, most notably by the UK Government and the British Geological Society (BGS). ${ }^{117}$ Shale beds are not found all over the UK. In England the most promising areas were quickly identified in several studies: the Bowland-Hodder study of June 2013; the Weald Basin study of May 2014 and in Scotland, the Midland Valley of Scotland study of June $2014 .{ }^{118}$ These reports and the wider DECC-BGS report supported the view that shale gas reserves 'could be' significant. However, one report noted: 'The untested shale rock volume in the UK is very large; however, more drilling, fracture stimulating, and production testing is necessary to prove that shale gas development is technically and economically viable. Even if one assumes that the American shale gas producing analogies are valid, many of the

\footnotetext{
${ }^{116}$ BEIS, 2017. Digest of UK Energy Statistics (DUKES) 2016 - Chapter 4: natural Gas <https://www.gov.uk/government/uploads/system/uploads/attachment_data/file/632523/Chapter_4.pdf>. ${ }^{117}$ BGS, 2018. Shale gas <http://www.bgs.ac.uk/research/energy/shaleGas/home.html> See also the BEIS <https://www.gov.uk/government/organisations\#department-for-business-energy-and-industrial-strategy> Other studies were carried out: for example, Shale Gas Extraction in the UK: A Review of Hydraulic Fracturing (2012), The Royal Society/Royal Academy of Engineering; Independent Expert Scientific Panel - Report on Unconventional Oil and Gas (2014), The Scottish Government.

${ }^{118}$ House of Commons Library, 2017. Shale gas and fracking - Briefing Paper Number 6073, 13 April 2017 <http://researchbriefings.parliament.uk/ResearchBriefing/Summary/SN06073\#fullreport> accessed 12 July 2018.
} 
operating conditions are different in the UK'. ${ }^{119}$ There was therefore some uncertainty about the results. Uncertainty about technically recoverable reserves of shale gas and oil was further supported by a 2012 report from the UK Energy Research Centre (UKERC). ${ }^{120}$ Despite this, the UK Government has repeatedly affirmed in policy statements that shale gas could materially contribute to the UK's energy security and offer economic benefits, a position unsurprisingly supported by companies heavily involved in the UK shale gas sector. Its estimates have been criticised as overoptimistic by the BGS. ${ }^{121}$

\section{The legal and policy framework}

The framework for energy policy in the UK is more complex than in many countries, with shared competencies distributed across international, national and sub-national tiers of government. ${ }^{122}$ As a Member State of the EU (and for some years following its withdrawal), the UK must comply with EU law, including its legislation on energy, health and safety and environment. In these areas however, competences are often shared or left to the national rather than the EU level. ${ }^{123}$ Within the UK, a devolved governance structure operates so that certain legislative powers reside in separate devolved governing bodies in Scotland, Wales and Northern Ireland. Under this arrangement, legislative powers are separated into 'reserved' matters remaining under the full jurisdiction of the UK and devolved matters that are placed within the jurisdiction of the devolved areas.

\footnotetext{
${ }^{119}$ DECC, 2013. Unconventional Hydrocarbon Resources of Britain's Onshore Basins - Shale Gas <https://www.gov.uk/government/uploads/system/uploads/attachment_data/file/367287/Shalegas_uk.pdf> p 32, accessed 12 July 2018.

${ }^{120}$ UKREC, 2012. A review of regional and global estimates of unconventional gas resources - September 2012 <http://www.ukerc.ac.uk/asset/A72A2DC5-B646-41C2-B392B8F552246C5A/> accessed 12 July 2018.

${ }^{121}$ Cuadrilla, 2016. About Natural Gas <http://www.cuadrillaresources.com/what-we-do/about-natural-gas/> accessed 12 July 2018.

122 Department for Trade and Industry, 2007. Meeting the Energy Challenge: A White Paper on Energy - May 2007 <https://www.gov.uk/government/uploads/system/uploads/attachment_data/file/243268/7124.pdf> accessed 12 July 2018.

${ }^{123}$ An exception is the Recommendation adopted by the European Commission on 22 January 2014 on safeguarding principles that Member States should implement to regulate shale gas operations. This is not legally binding. It sets out as minimum requirements the following: a requirement for operators to carry out a risk assessment and a baseline environmental study before they start operations; a requirement that operators provide a financial guarantee or equivalent that covers their obligations under permits and potential liabilities for environmental damage; and a requirement for a survey to be made after each installation's closure to compare the environmental condition of the site with its pre-operational state as set out in the baseline study.
} 
In energy terms, the effect of devolution is that the UK authorities have reserved powers over the generation, transmission, distribution and supply of electricity; the ownership, exploration and exploitation of hydrocarbon deposits; coal (including its ownership and exploitation) and nuclear energy and nuclear installations. Devolved matters include powers over related areas such the environment, planning and some economic development, including fiscal powers. It is worth noting that dividing responsibilities between the UK and devolved governments in this way has not led to a clear separation of powers in practice. ${ }^{124}$

At the national level, it is the UK as the sovereign state that holds key responsibilities for meeting international (e.g. the Paris Agreement) and EU (e.g. the 2009 Renewable and Climate Change Directive) commitments. As such, it is the UK Government, primarily through the Department for Business, Energy and Industrial Strategy (BEIS) ${ }^{125}$ and the UK Treasury, that designs the wider electricity market and the main policy instruments to promote several types of energy (e.g. renewables, nuclear, shale gas). They also hold oversight responsibility for regulating both the energy sector and energy networks via the Office for Gas and Electricity Markets (OFGEM), a pan-UK independent energy regulatory body alongside other bodies including the Crown Estate and National Grid. It is also the UK Government that participates directly in negotiations at the international level on the direction of current and future energy relevant policy. ${ }^{126}$ Other agencies play a role in unconventional resource development. Two require mention. The Environment Agency is the environmental regulator for all onshore oil and gas operations in England, including: Shale gas; Coal bed methane; and Underground coal gasification. Following devolution in 1997, there have been several changes to the institutional and regulatory landscape in the devolved administrations. Since the Offshore Safety Act 1992, health and safety has not been a factor BEIS checks when considering

\footnotetext{
${ }^{124} \mathrm{G}$ Wood and K Baker, A Critical Review of Scottish Renewable and Low Carbon Energy Policy (Palgrave Macmillan 2017).

${ }^{125}$ Newly established in 2016, BEIS incorporates energy issues from the now defunct Department of Energy and Climate Change (DECC).

${ }^{126}$ Wood and Baker (n 124).
} 
the competence of an operator. This is wholly the responsibility of the Health and Safety Executive (HSE), an independent regulator, responsible for enforcing health and safety legislation in workplaces.

The above complex structure has given rise to concerns that there is a 'regulatory maze' which could act as a deterrent to new investors. For that reason, the UK Government has issued guidance notes for investors about how to address matters such as applications for planning consents.

\section{Regulating to promote unconventional hydrocarbons}

\section{Adaptation of the existing licensing regime}

In regulatory terms, unconventional energy has been developed to date as a sub-set of the established regime for conventional hydrocarbons. Although a pragmatic choice, this implicitly set to one side the distinct features of unconventional resource development. The starting point is that in the UK, as in most countries, ownership of underground hydrocarbons is vested in the State, or in this case the Crown. Responsibility for managing the sector lies with the Secretary of State for Energy, whose department-the $\mathrm{BIES}^{127}$ - is responsible for setting energy policy and establishing the framework for achieving policy goals. BEIS is responsible for petroleum licensing of onshore and offshore activities, including decommissioning of oil and gas installations and pipelines, as well as enforcing environmental legislation. The department has set up the Office for Unconventional Gas and Oil (OUGO) to 'promote the UK's unconventional reserves of gas and oil', including shale gas and oil.

The conventional sector has been regulated by means of licences, usually awarded following rounds of bidding that since 1994 must be publicly advertised in the Official Journal of the European Union. ${ }^{128}$ The onshore licensing system distinguishes between the exploration and production stages

\footnotetext{
$127<$ https://www.gov.uk/government/organisations/department-of-energy-climate-change/about> accessed 12 July 2018.

${ }^{128}$ Directive 94/22/EC of the European Parliament and the Council of 30 May 1994.
} 
with different licences, ${ }^{129}$ with production licences divided according to the specific features of the area and the company that is applying for them. ${ }^{130}$ The licence conditions are published in statutory instruments under the Petroleum Act 1998 and are known as model clauses. They are quite detailed in character.

The key licence for a company seeking to carry out onshore hydrocarbons exploration and development is the Petroleum Exploration and Development Licence (PEDL). This grants the holder the exclusive right to pursue a range of oil and gas exploration activities, subject to necessary drilling/development consents and planning permission. Each PEDL confers such rights over a limited area and for defined phases. Exploration can last for three years (from 2014) while up to six years was previously the norm for onshore hydrocarbons exploration. Appraisal can last for five years and requires the holder to draw up and submit a field development plan. The production phase for oil and natural gas is 20 years with a possible extension. Unless the licensee has made sufficient progress as the end of each phase to move to the next phase, it will expire. At the end of the exploration phase, no less than 50 per cent of the acreage must be given up. For shale gas reserves however, which are likely to be spread over a much wider area than conventional gas reserves, such a relinquishment obligation would be a disincentive. This was modified in 2014 , so that this obligation is subject to a new power for the Minister to agree with the licensee on the establishment of Retention Areas and Development Areas: if the licensee company seeks to make a part of its Licensed Area into a Retention Area, it must submit a Retention Area Plan describing the exploration and appraisal activities that the licensee intends to carry out in the Retention Area. The Minister can approve this application and the licensee retains the area sought into the second term. The same can happen with a Development Area. It is also possible for the licensed area that is surrendered or retained to be identified in three rather than two dimensions.

\footnotetext{
129 The Petroleum Licensing (Exploration and Production) (Seaward and Landward Areas) Regulations 2004. ${ }^{130} \mathrm{G}$ Gordon, J Paterson and E Üşenmez, Oil and Gas Law-Current Practice and Emerging Trends (Dundee University Press 2011) 71.
} 
When this onshore licensing regime was expanded to include shale gas and oil, there wereinitially at leas-only a few differences between them. The predecessor of BEIS advised in 2013 that there is no firm licensing distinction between exploration for shale gas and exploration for conventional oil and gas. Some companies which are drilling mainly for conventional oil and gas have decided to drill deeper than they otherwise might have, to see whether there is prospective shale in their licensed areas.

Before fracking can take place, however, certain permitting requirements beyond those in the PEDL need to be complied with. A 2013 'regulatory roadmap' noted the following 'four' consents as required before a licensee could commence full exploration activity: environmental consents; departmental consent to drill a well and undertake fracturing; planning permission; and land access consents from landowners. In the UK the focus is on requirements for consents that are necessary for shale gas (rather than oil) exploration and not production since none is yet taking place. Where the licensee seeks to progress from exploration to production, it will need to go through a second round of regulatory consents. Given the lack of experience of this phase by regulators, it can be assumed that this part of the process is still evolving.

Some brief comments on each of these four consent processes seems necessary to fill in an important regulatory space. The first set of consents required by shale gas operators includes mining waste permits; a water abstraction licence; groundwater activity permits; radioactive substances activity permits; and assessment and approval of chemicals used for hydraulic fracturing. An Environmental Impact Assessment (EIA) may also be required.

The second set of consents relates to drilling and is obtained from the government department. They are influenced by an incident in northern England in 2011, where earth tremors were alleged to have been triggered by the UK's first shale production test. Now, shale gas operators are required to: assess the seismic hazards presented by hydraulic fracturing activity in each well site area; monitor the seismic activity of the well site area and develop and implement a mitigation plan 
for possible earthquakes caused by hydraulic fracturing. A real-time trigger has also to be installed that will act to cut off injection into a well if there is a significant risk of an earthquake.

A third set of consents concerns planning permission. In England and Wales this is managed by the Minerals Planning Authorities (MPAs), which have responsibility for planning control of works carried out in connection with mineral development. The MPAs are required to carry out consultations and decide on an application within 13 weeks. The considerations they have to take into account relevant to unconventional resource development include: air quality, traffic, risk of contamination to land, wildlife; and land stability.

Finally, there are consents from the relevant landowners. In contrast to large parts of the US, landowners in the UK do not own the resources in the ground and so they are not entitled to sell shale gas or oil reserves located under their land. However, they are entitled to compensation through land access agreements paid by a shale operator (for rights of access and the location of the drilling pad itself). A company seeking access is also required to have permission from all landowners under whose land they drill. This has been modified however, as is discussed below in the Section 'Challenges and locally crafted solutions'.

The UK has, alongside Norway, one of the most stringent onshore drilling safety regimes in the world. The Health and Safety Executive (HSE) monitors shale gas operations from a well integrity and site safety perspective. They are charged with ensuring that safe working practices are adopted by onshore operators as required under the Health and Safety at Work Etc., Act 1974. Regulations made under the Act include:

- The Borehole Site and Operations Regulations 1995 (BSOR) applies to shale gas operations. (These regulations are primarily concerned with the health and safety management of the site).

- The Offshore Installations and Wells (Design and Construction, etc.) Regulations 1996 (DCR) apply to all wells drilled with a view to the extraction of petroleum regardless of whether they are onshore or offshore. 
The above regime was first used for unconventional energy in 2008 with the grant of a promote (exploration) license to Cuadrilla Resources and Lucas Energy. The license included a working programme of $400 \mathrm{~km}$ of $2 \mathrm{D}$ seismic data in the first part of the initial term and a drill or drop commitment for well of 1000 metres in depth.

\section{Specific initiatives and innovations}

The UK Government has been proactive in its express policy support for a shale gas sector. Initially, in its own version of Shale 1.0, it simply adapted the existing regime for conventional hydrocarbons development to the harnessing of unconventional resources. At the same time, it faced public concerns about safety and environmental issues which led briefly to the imposition of a moratorium on development while ongoing research was completed into a number of issues. The context of public concern and uncertainty about resource potential had the effect of preventing the emergence of a new industry in unconventional resources. The regulatory regime was one of the variables which government was able to affect if it chose to do so. Several initiatives were subsequently taken, with three notable changes to the regulatory regime: planning rules; faster processing of shale gas licence applications; and improved rules for infrastructure provision.

Planning permission. In England and Wales, proposals for shale gas exploration or extraction are subject to the requirements of the Town and Country Planning Act 1990 administered by the MPAs for the area in which the development is located. Consents and other permissions are only provided by BEIS once planning permission has been obtained by the MPA.

Planning decision-making is based in accordance with the policies set out in the National Planning Policy Framework (NPPF) and the 'minerals' section of the online Planning Practice Guidance (PPG). Furthermore, when a decision is made on a planning application, only planning matters called 'material considerations' can be taken into account. There is no exhaustive list of what constitutes a material planning consideration, although the PPG lists some 'principal issues' for consideration. These can include: noise associated with the operation; dust; air quality; lighting; 
visual impact; landscape character; traffic; risk of contamination; land stability/subsidence;

ecological/biodiversity importance; surface and ground water issues and water abstraction.

The UK Government has been consulting on changes to the NPPF to provide very implicit

support for shale gas from MPAs. Currently, the NPPF says:

When determining planning applications, local planning authorities should give great weight to be benefits of mineral extraction, including to the economy'.

The Government wants to change this to 'Minerals planning authorities should: 'recognise the benefits of on-shore oil and gas development, including unconventional hydrocarbons, for the security of energy supplies and supporting the transition to a low-carbon economy; and put in place policies to facilitate their exploration and extraction' ${ }^{131}$

Faster decisions on shale gas planning applications. Other changes to speed up planning decision-

making have included removing the need in 2014 to notify individual owners of land and tenants on ground where only underground operations may take place (ie not the actual above ground development). ${ }^{132}$ In 2015, the UK Government announced a number of additional measures aimed at the shale gas sector. ${ }^{133}$ The Secretary of State for Communities and Local Government will make the final decision on planning appeals related to exploring and developing shale gas, thus removing the role of the planning inspector. This change is limited to a two-year period, although it might be extended.

\footnotetext{
${ }^{131}$ Ministry of Housing, Communities and Local Government, 2018. National Planning Policy Framework: Draft text for consultation - 5 March 2018 <https://www.gov.uk/government/uploads/system/uploads/attachment_data/file/685289/Draft_revised_Nat ional_Planning_Policy_Framework.pdf>p 58, accessed 12 July 2018.

${ }^{132}$ Town and Country Planning (Development Management Procedure and Section 62A Applications) (England) (Amendment No 2) Order 2013 (SI 2013/3194). Note too the various changes proposed in a Written Statement from the Secretary of State for Business, Energy and Industrial Strategy in May 2018 $<$ https://www.parliament.uk/business/publications/written-questions-answers-statements/writtenstatement/Commons/2018-05-17/HCWS690/> accessed 12 July 2018.

${ }^{133}$ DECC and Ministry of Housing, Communities and Local Government, 2015. Policy Paper-Shale gas and oil policy statement-13 August 2015 <https://www.gov.uk/government/publications/shale-gas-and-oil-policystatement-by-decc-and-dclg> accessed 12 July 2018. In May 2018 further measures were introduced in an Energy Policy Written Statement <https://www.parliament.uk/business/publications/written-questionsanswers-statements/written-statement/Commons/2018-05-17/HCWS690> accessed 12 July 2018; proposals for a Shale Wealth Fund were discussed in an official paper in November 2017 $<$ https://assets.publishing.service.gov.uk/government/uploads/system/uploads/attachment_data/file/658793 /shale_wealth_fund_response_web.pdf> accessed 12 July 2018.
} 
The Secretary of State for Communities and Local Government also has powers to 'call-in' shale gas applications before they are decided by the local planning authority and identifying underperforming local planning authorities. The statutory deadline for determining a planning application where an application is subject to an Environmental Impact Assessment (EIA) is 16 weeks. The UK Government would identify underperforming local planning authorities that 'repeatedly fail' to determine oil and gas applications within statutory timeframes. When such applications are made to underperforming local planning authorities, the Secretary of State will be able to consider whether to determine the application instead of the local planning authority.

Opposition to fracking has usually been expressed through delays and problems on the licenses granted by local councils in the use of land. The Government decided to increase the competence of the Secretary of State for Communities and Local Government, by giving the said Secretary of State the capacity to act as final decision-maker on appeals for licenses related to shale gas developments. In addition, the same public officer has the power call in shale gas applications before they are decided and to identify underperforming local planning authorities. This increase and centralization of power in Westminster (at the UK Government level) over local decisions is an approach that demonstrates the importance of shale gas developments for a national energy strategy. However, it also opens up shale gas to policy or political risk, for example in the event that a government is elected that opposes shale gas development in the UK or the devolved nations: this has already occurred in Scotland which has banned shale gas exploitation (see also Section 'Challenges and locally crafted solutions').

At a site in England where licences have been granted to Cuadrilla Resources, work had not yet started after six years. ${ }^{134}$

This provided the context and impetus to a new package of measures in May 2018. The main elements of this were: a streamlining of the regulation process for applications to ensure decisions

134 Jillian Ambrose, 2018. Fracking firm Cuadrilla to reignite West Sussex plans. 
are made in a timely manner. This includes establishment of a Shale Environmental Regulator and a Planning Brokerage Service. Noting that the Oil and Gas Authority also has a role in regulation, the initiative tries to bring the regulators together to act as a single coherent face for the public, mineral planning authorities and industry. It will operate in England only. In addition, there is a shale support fund to build capacity in local authorities when dealing with shale applications. Earlier, in the autumn of 2017, a Shale Wealth Fund had been established to provide additional resources to local communities, to supplement funds offered by industry to local communities.

The Infrastructure Act 2015. This is a major piece of legislation that aims to streamline the underground access regime to make it easier for companies to drill for shale gas. ${ }^{135}$ Under the previous system, licence holders did not have automatic access rights to drill under landowners' property and had to seek permission before they could do so. If permission was refused, then licence holders could apply through the Secretary of State and courts to gain access, but the Government considered this route to be too time consuming. This effectively removes trespass rights for landowners for underground access below 300 metres. The Act did make provision for landowner compensation from the development but left the onus on proving any damage or disruption on the landowner, which carries additional expenses and risks. The Infrastructure Act 2015 also extended the Community benefits approach developed for the onshore wind sector to shale gas. Under this approach, the industry agreed to pay $£ 100,000$ to communities per hydraulically fractured well site at the exploratory stage, and 1 per cent of revenue if it successfully goes into production. In addition, the industry confirmed that operators would contribute a voluntary one-off payment of $£ 20,000$ for the right to use deep-level land for each unique lateral well that extends by more than 200 metres and would notify the public when exercising this power.

\footnotetext{
135 It is worth noting that the Infrastructure Act 2015 changes to the underground access regime will also apply to geothermal energy.
} 
Environmental considerations. The potential effects that shale gas development may have on the environment are a paramount concern for a portion of the society in the UK, which has expressed it through public demonstrations, such as the one that occurred in Lancashire in 2013, and elsewhere around the UK where shale gas activities are planned or taking place. ${ }^{136}$

One of these concerns refers to the potential contamination of water through a leak on the integrity of the well. This issue was raised by the UK House of Commons Energy and Climate Change Committee inquiry in 2011,137 and the government reiterated in their response to the inquiry findings that the regulatory agencies in charge of energy and petroleum have dealt with lateral drilling and fracturing before, thus meaning that they have existing current technical capability to regulate this new industry. Referring to the integrity of the well, a scheme to prevent contamination in offshore well was has also been applied before, and it is also applicable for this purpose. ${ }^{138}$ In addition, the Royal Society and the Royal Academy of Engineering considered that because fracking occurs at a considerable distance from aquifers, it is not very likely that they may be affected by the fracturing operation. ${ }^{139}$

Fracking has a very intensive use of water, which has been highlighted as another cause for concern. According to the UK Government in 2016, the use of water would depend on the requirements of each site, and the heavy regulatory process for the use of water, would provide enough opportunities to evaluate the sustainable use of water, allowing the relevant regulators to

\footnotetext{
${ }^{136}$ BBC. Frack Off Protesters rig blockades. 18 June 2012.

${ }^{137}$ House of Commons Energy and Climate Change Committee, 2011. Shale Gas-23 May 2011 $<$ http://www.parliament.uk/business/committees/committees-a-z/commons-select/energy-and-climatechange-committee/inquiries/shale-gas/> accessed 12 July 2018.

${ }^{138}$ House of Commons Library, 2017. Briefing Paper Number 60703: Shale gas and fracking 13 April 2017 <http://researchbriefings.parliament.uk/ResearchBriefing/Summary/SN06073> accessed 12 July 2018. ${ }^{139}$ The Royal Society and the Royal Academy of Engineering, 2012. Shale gas extraction in the UK: a review of hydraulic fracturing-June $2012<$ https://royalsociety.org/ /media/policy/projects/shale-gas-extraction/201206-28-shale-gas.pdf > accessed 12 July 2018.
} 
make decisions on the licenses for the use of water, without endangering the supply of such an important liquid. ${ }^{140}$

The disposal of the water used or produced during the fracking process has also been a controversial issue in several jurisdictions, including the UK. Current EU and UK regulation do not allow the re-injection of the water into the well, and therefore it needs to be processed and disposed elsewhere. ${ }^{141}$

In April 2011, some seismic events occurred near an area where fracking operations were carried out and the company involved stated that they would postpone operations. The response from the UK Government was to impose a moratorium that lasted for 10 months. ${ }^{142}$ The BGS as well as the Environmental Agency carried out studies and in December 2012, fracking activities resumed.

Today the regulation includes additional requirements such as:

- Conduct a prior examination of existing faults and seismic risks.

- Submit a report to BEIS on how seismic risk would be addressed.

- Implement seismic monitoring before and during the fracturing job, including the use of the 'traffic light' system to establish to continue, reassess or stop the fracking activity. ${ }^{143}$

An example of the influence of the American experience is that of the need to share any resultant financial benefits from shale gas developments with the communities that must bear the effects associated with shale gas exploration and production. Even though the principles and systems of ownership of resources underground is very different between the UK and the US, the idea to provide additional benefits to land owners and residents of the area where the fracking activity takes place appears like the individual compensation that occurs in the US, primarily due to the private ownership of underground resources. Therefore, the possibility that the companies agree to pay $£ 100,000$ to communities per hydraulically fractured well site at the exploratory stage,

\footnotetext{
${ }^{140}$ House of Commons Library, 2017. Briefing Paper Number 60703: Shale gas and fracking 13 April 2017 <http://researchbriefings.parliament.uk/ResearchBriefing/Summary/SN06073> accessed 12 July 2018. ${ }^{141} \mathrm{MC} O$ ' Donnell and others, 'Wastewater from Hydraulic Fracturing in the UK: Assessing the Viability and Cost of Management' (2018) 4 Environmental Science: Water Resources and Technology. 142 Thomson Reuters. Government lifts moratorium on UK shale gas hydraulic fracturing. 22 January 2013. ${ }^{143}$ Oil and Gas Authority. OGA Traffic Light Monitoring Scheme to mitigate induced seismicity. 2017.
} 
and 1 per cent of revenue if it successfully goes into production, creates a new model of private compensation for the residents instead of providing general compensation to society only through taxes and royalties.

The government has issued for public consultation a proposal to create an allowance for shale gas exploration and production that would reduce the tax portion on the income from a company from 62 per cent to 30 per cent. ${ }^{144}$

Experience of other jurisdictions, such as the US, on how to face the potential risks, becomes useful for the new developments in the UK. An example of this is the fact that the re-injection of water cannot be carried out in the UK, following the lead of North Carolina, ${ }^{145}$ and looking to avoid the potential effects on seismic activity that such practice may have.

What is clear is that the UK Government approach to supporting a domestic UK shale gas sector is focused heavily on their view of unconventional fossil fuels as a "potential economic prize" ${ }^{146}$ This largely ignores domestic and international legally-binding climate change and other environmental obligations. Further, it highlights the role of ideology in UK energy (and environmental) policy making, with shale gas appearing as a favoured energy technology (along with nuclear power and conventional gas) in stark contrast to renewables. ${ }^{147}$

\section{Challenges and locally crafted solutions}

The initial approach of adapting the current licensing system for conventional resources for a new use and maintaining the jurisdiction of already existent government bodies on the design of policy and regulation of the subject have both proved insufficient. Various new initiatives have been

\footnotetext{
$144<$ https://www.gov.uk/government/consultations/harnessing-the-potential-of-the-uks-natural-resources-afiscal-regime-for-shale-gas/harnessing-the-potential-of-the-uks-natural-resources-a-fiscal-regime-for-shalegas\#pad-allowance> accessed 12 July 2018.

${ }^{145}$ Resources for the Future. The State of State Shale Gas Regulation. May 2013, p 53.

${ }^{146}$ Economic Affairs Committee, 'The Economic Impact of Energy Policy on Shale Gas and Oil' (House of Lords, May 2014) para 298.

${ }^{147}$ Geoffrey Wood, 'Written Evidence to the Economics of UK Energy Policy Inquiry' (Economic Affairs Committee, House of Lords, September 2016) <http://data.parliament.uk/writtenevidence/committeeevidence.svc/evidencedocument/economic-affairscommittee/the-economics-of-uk-energy-policy/written/39645.pdf> accessed 30 July 2018.
} 
required, from OUGO to the Shale Environmental Regulator and a possible Shale Wealth Fund, to demonstrate the commitment of the UK Government in developing this resource and have become key elements of UK energy policy-making.

Regulatory divergence inside the UK is a factor that impacts on the prospects for unconventional development. The Scotland Act 2016 devolved shale gas licensing to the Scottish Parliament, and the Wales Act 2017 includes provisions to devolve shale gas licensing to the National Assembly for Wales. To date, the devolved administrations had adopted a negative approach to unconventional resource development. In 2015, the Scottish Government announced a moratorium on fracking in Scotland which was extended to an outright ban in 2017. In 2015, the Welsh Government issued a Direction preventing local planning authorities from approving developments which included fracking, ${ }^{148}$ while in the same year the Northern Ireland Assembly included a 'presumption against' fracking in planning policy guidance. ${ }^{149}$ Subsequent to the decisions against unconventional hydrocarbons in the devolved nations, the main UK opposition party (The Labour Party) announced that it would ban fracking when next in government. ${ }^{150}$

\section{Foreign Influence}

Previous experience has shown that the US shale gas revolution was led by US-based 'wildcat' independents ${ }^{151}$ whilst in Argentina foreign-owned, typically multi-national companies have driven development (see Colombia Case Study above). An examination of the ownership of companies involved in the development of the UK shale gas sector reveals a slightly different story, with indications that all is not well in the UK.

\footnotetext{
148 The Welsh Government, 2017. The Town and Country Planning (Notification) (Unconventional Oil and Gas) Wales Direction 2015 <http://gov.wales/topics/planning/policy/dear-cpo-letters/unconventional-oil-andgas/?lang=en> accessed 12 July 2018.

${ }^{149}$ Northern Ireland Planning Portal, 2015. Strategic Planning Policy Statement for Northern Ireland-Planning for Sustainable Development (SPPS) <https://www.planningni.gov.uk/spps> accessed 12 July 2018.

${ }^{150}$ BBC News, 2016. Labour vows fracking ban if it wins general election-26 September 2016 <http://www.bbc.co.uk/news/uk-politics-37470549> accessed 12 July 2018.

${ }^{151}$ Gregory Zuckerman, 'The Frackers: The outrageous inside story of the new billionaire wildcatters' (Penguin Random House, October 2014).
} 
Currently, there exists a diverse mix of large and small UK and foreign-based or owned companies involved in the fledgling UK shale gas sector. By far the biggest player is Ineos, a privatelyowned multinational chemicals company headquartered in the UK. Two other key shale gas specialist companies include Cuadrilla Resources Ltd., a privately-owned company headquartered in the UK and IGas, an independent oil and gas exploration and production company, also based in London (which also owns Dart Energy, a subsidiary of IGas). Other key companies include the French energy giants Total and GDF Suez (Engie); UK-based Centrica the owner of British Gas, one of the 'Big Six' UK energy companies); Canadian-owned Cirque Energy; Third Energy and less well-known companies including Egdon Resources (London-based), Hutton Energy (UK-based), Aurora Energy Resources (UK-owned), Osprey Petroleum (UK-owned) and Aberdeen Drilling Management (ADM). ${ }^{152}$ Of interest, a number of these companies are or until recently were in partnership with each other to develop a number of sites (e.g. Ineos and Engie, Ineos and Egdon and IGas). ${ }^{153}$

This reflects a position somewhere between the US and Argentinian experiences. In part, it reflects the prolonged infancy stage of the UK shale gas sector, enabling independent and smaller companies to gain entrance (also partly brought on by the other reasons outlined elsewhere in Section 5). However, the presence of large-scale multinationals at such an early stage also appears to reflect an acceleration of the US experience. At the same time, the acquisition of GDF Suez's Engie shale gas portfolio (15 licences) by Ineos appears to indicate a shift in ownership and appetite brought on by a scepticism of UK shale prospects and increasingly attractive markets elsewhere (e.g.

\footnotetext{
152 Frack Off, 'Fracking Companies' <http://frack-off.org.uk/locations/bad-guys/> accessed 12 July 2018; David Hellier, 'Fracking: who's who in the race to strike it rich in the UK' (The Observer, August 2015) <https://www.theguardian.com/business/2015/aug/22/fracking-uk-whos-who-in-race-to-strike-it-rich> accessed 30 July 2018.

${ }^{153}$ David Hellier, 'Fracking: who's who in the race to strike it rich in the UK' (The Observer, August 2015) $<$ https://www.theguardian.com/business/2015/aug/22/fracking-uk-whos-who-in-race-to-strike-it-rich> accessed 12 July 2018.
} 
renewables, power). Indeed, the selling of its UK shale gas portfolio is part of a wider withdrawal from oil and gas. ${ }^{154}$

At this early stage, it is difficult to tell what this means. What is clear is that the removal of UK hurdles to shale gas exploitation and commercialisation are needed before the majors move in strength into the UK domestic market.

\section{Assessment}

The UK has taken an approach based on the robustness of its already existing regulatory framework, and its applicability to unconventional hydrocarbons. The assumption seems to have been that decades of experience with conventional resource regulation-primarily offshore-make this existing set of legal instruments suitable, particularly when backed by the proven technical capacity of the personnel in charge of enforcing it. However, the technical reality of unconventional hydrocarbons is very different than those facing offshore exploration and production activities, and additional risks have needed to be addressed, requiring the modifications summarized in this section. This is a lesson that surely should have been learnt from the early deployment of renewable energy technologies, which suffered similar problems in government attempts to deploy them using existing regulatory structures. ${ }^{155}$

The creation of an agency to promote unconventional hydrocarbons (OUGO), modifications to the powers of the central government in local issues, and changes in regulations for underground drilling, appear to demonstrate this need to adapt.

The evolving character of the UK's constitutional framework has created obstacles for the scope of unconventional resource development in the UK. The total ban in Scotland and the strong position against fracking in Northern Ireland and Wales contrast strongly with the approach taken by

\footnotetext{
${ }^{154}$ Andrew Ward, 'Ineos boosts efforts to bring UK-style fracking to UK' (Financial Times, March 2017) <https://www.ft.com/content/95170148-04b8-11e7-aa5b-6bb07f5c8e12> accessed 12 July 2018. ${ }^{155}$ Geoffrey Wood and Stephen Dow, 'What lessons have been learned in reforming the Renewables Obligation? An analysis of internal and external failures in UK renewable energy policy' (Energy Policy, May 2011).
} 
the central government and limit or prohibit the growth of unconventional resource operations in these parts of the UK. Even in England, the need to adapt the established regime to allow greater engagement by local communities and authorities indicates that challenges remain, which are analogous to those facing most infrastructure projects.

Overall, despite policy and regulatory interventions to support the growth of an unconventional resource industry in much of the UK, shale gas and oil drilling remain after several years at an exploratory stage and industry's efforts to improve their knowledge of the true level of commercial reserves is modest. No commercial operations have yet commenced.

\section{CONCLUSIONS}

Table 3 provides a summary of the main features of Shale 1.0 in the first column and lists the responses of the three countries in the next three columns. There are significant differences in response, with the UK probably emerging as the one most likely to follow the US in the development of shale resources, despite territorial restrictions and ongoing issues with respect to the social licence to operate.

Ownership. A defining feature of the economic success of Shale 1.0 was the ownership arrangements characterizing hydrocarbons development in certain parts of the USA. The land owner owned the hydrocarbons and had a commercial incentive to participate in shale gas development. Replicating that financial incentive to landowners in a regime with state ownership of the resources is, as the UK example demonstrates, a challenge. This is not a matter of lacking a social licence to operate but rather finding a substitute for an important commercial incentive. The ability of companies to secure rights from private owners of land quickly was one of the key variables for that early success which cannot be replicated outside of the USA, where public ownership of hydrocarbons is the norm.

However, the case studies suggest that this observation may be less fundamental than it appears. In each case, the national authority has sufficient legal powers to create arrangements that 
can offer private investors similar and sufficient legal security to be able to support unconventional resource activity. However, as in many parts of the USA and Canada, local (or Provincial or State) authorities have legal competences in areas that would allow them to delay or hold up projected developments in densely populated areas. In Colombia, local community preferences (rather than those of private landowners) will play a decisive role in the future of unconventional resource development.

Infrastructure. Availability of local infrastructure is a key consideration which in many cases involves its construction. Argentina has made extensive efforts to encourage this. However, the effects of its elaborate local content policy in this and other respects are still unclear. As a way of improving the benefits to the national economy of shale development this policy emphasis emulates the approach taken in many countries with respect to conventional hydrocarbons development, and is likely to become a feature of many government policies.

Environment. The environmental aspect is also less straightforward than it may seem. In principle, there is no reason why environmental laws cannot be adjusted to address the challenges of new technologies such as fracking. If this is one of the reasons behind the lack of a social licence to operate, it seems capable of being addressed and over time improved upon.

Regulation. Regulatory authority responsible for oversight and monitoring can be designed to ensure that it avoids conflicts of interest and where more than one body exists, that cooperation among agencies is achievable. UK experience suggests that a single government body for managing environmental issues connected with proposed shale development may be required if promotion of investment is a policy goal. A key area is the relationship between conventional and unconventional activity on the same area. This can be positive and negative, and ought to be anticipated in the design of regulations to maximize potential gains for the host state and minimize uncertainties for the investor. 
Macroeconomic and social considerations. In each case there was an impact of wider, nonenergy considerations on the policy choices. In Argentina's case, the shale sector is influenced by the country's wider economic problems in its recent history and efforts to move beyond them; in Colombia the recent civil conflict leaves a legacy that threatens infrastructure in this area; and in the UK the rapid decline in revenues from North Sea oil and gas have returned the economy to energy dependence on external sources after a period of several decades, leading to a search for new choices in the energy mix.

Outcomes for further consideration. There has been little in this study to suggest that the diversity in state structures, from federal to provincial to local, creates a major fact of difference between them. Similarly, the mix of civil and common law regimes has not yielded any points of difference in the various country studies. These differences may exist but are not evident in this study. It may also be the case that further examination of tax and fiscal arrangements could be carried out for the host state and for foreign and local investors. This goes beyond the scope of the present study.

In determining the pace of establishment of shale operations in Shale 2.0, an important factor will be the application of generally accepted regulatory and contractual practices. The developments in the countries examined in this article in the light of their own special and even unique country settings may contribute to the development of government responses to industry interest in shale resource development. In each case considered here, the governments were alive to the benefits of greater energy independence which the development of unconventional hydrocarbons resources appears to offer. At the same time, where the social impact of shale gas development is likely to be high such as in areas with high-population density (and Argentina is the exception here), opposition to this energy choice is likely to be significant. 
Table 1. Shale wells drilled and completed

\begin{tabular}{lrrr}
\hline Year & YPF & Others & Total \\
\hline 2011 & 20 & 2 & 22 \\
2012 & 25 & 22 & 47 \\
2013 & 104 & 29 & 133 \\
2014 & 160 & 23 & 183 \\
2015 & 178 & 22 & 200 \\
2016 & 103 & 17 & 120 \\
2017 & 64 & 45 & 109 \\
Jan-Apr 18 & 23 & 33 & 56 \\
TOTAL & 677 & 193 & 870 \\
\hline
\end{tabular}


Table 2. Content of regulations on unconventional hydrocarbons E\&P

\begin{tabular}{|c|c|}
\hline Subject & Measures \\
\hline $\begin{array}{l}\text { Plan for previous use of hy- } \\
\text { draulic fracturing }\end{array}$ & $\begin{array}{l}\text { 1. The superficial coating must be cemented up to the surface. } \\
\text { 2. The cementing process that must be used is pumping and sealing or a similar } \\
\text { one that allows settling of the cement. } \\
\text { 3. Superficial coat must be built to a depth not less than } 150 \text { feet under any ac- } \\
\text { quirer that could be used for human consumption. } \\
\text { 4. It is necessary to carry out pressure test to the casing and dementing. } \\
\text { 5. In case there is any problem with cementing or casing, it must be reported } \\
\text { to the authorities, the activities must be suspended immediately }\end{array}$ \\
\hline Use of hydraulic fracturing & $\begin{array}{l}\text { 1. Complete schedule of fracturing activity. } \\
\text { 2. Volumes used for the fracture, chemical agents present in the mixture, and } \\
\text { anticipated pressures of fracture. } \\
\text { 3. Radius of the hydraulic stimulation for every stage. } \\
\text { 4. Baseline of natural radioactive present in the local environment, and poten- } \\
\text { tial measures taken in case of its increase. } \\
\text { 5. A program of hydraulic stimulation that includes the high of the casing and } \\
\text { cementing, and an analysis that shows that the cementing and casing will be } \\
\text { able to resist the pressures caused by the stimulation. }\end{array}$ \\
\hline Use of Hydraulic Fracturing & $\begin{array}{l}\text { 1. Execute pressure test over the casing that may be expose to any hydraulic } \\
\text { fracturing activity. } \\
\text { 2. The operator must be permanently monitoring the pressure, and if it reaches } \\
\text { a limit }{ }^{149} \text {, the operation must be immediately stopped. } \\
\text { 3. In case of a leak within the pipes and the casing, the activity must be } \\
\text { stopped, and the authorities must be notified to act. } \\
\text { 4. The regulation establishes a formula to determine the minimum depth from } \\
\text { aquifers allowed to perform hydraulic fracturing. } \\
\text { - Hydraulic fracturing cannot be done within less than } 200 \text { meters of an } \\
\text { underground aquifer source of water for agriculture or human consumption. }\end{array}$ \\
\hline Re-injection of produced water & $\begin{array}{l}\text { 1. A general assessment of the geological formation. } \\
\text { 2. The measures and pressures of the lateral drilling and fractures of the well. } \\
\text { 3. Historic seismicity evidence within } 16 \mathrm{~km} \text { of the location of the well. }\end{array}$ \\
\hline $\begin{array}{l}\text { Activities that require previous } \\
\text { authorization by the Ministry } \\
\text { of Mines }\end{array}$ & $\begin{array}{l}\text { - Beginning of construction of the well. } \\
\text { - Cementing and casing. } \\
\text { - Test of the preventers. } \\
\text { - Test of casing and cementing. } \\
\text { - Pressure tests. }\end{array}$ \\
\hline
\end{tabular}


Table 3. Summary of shale gas country conditions in relation to Shale 1.0 template

\begin{tabular}{|c|c|c|c|}
\hline Shale 1.0: US Template & Argentina & Colombia & $U K$ \\
\hline $\begin{array}{l}\text { Ownership (private land- } \\
\text { owners with incentives } \\
\text { in key regions) }\end{array}$ & $\begin{array}{l}\text { State ownership but shar- } \\
\text { ing of powers with prov- } \\
\text { inces in federal } \\
\text { structure; energy policy } \\
\text { is federal competence }\end{array}$ & $\begin{array}{l}\text { State ownership, with a } \\
\text { revenue sharing } \\
\text { scheme with the pro- } \\
\text { ducing departments } \\
\text { and municipalities. } \\
\text { Private agreements can } \\
\text { be made with land- } \\
\text { owners and local com- } \\
\text { munities to improve } \\
\text { the processes of local } \\
\text { acceptance of the } \\
\text { operations. }\end{array}$ & $\begin{array}{l}\text { State ownership, with rev- } \\
\text { enue-sharing scheme for } \\
\text { local communities; land } \\
\text { access agreements give } \\
\text { compensation to land- } \\
\text { owners from shale } \\
\text { operators }\end{array}$ \\
\hline $\begin{array}{l}\text { Allocation of rights by } \\
\text { lease }\end{array}$ & $\begin{array}{l}\text { Extensive provincial } \\
\text { powers over licensing: } \\
\text { to extend licences; ap- } \\
\text { prove assignment; re- } \\
\text { voke and impose } \\
\text { penalties. New conces- } \\
\text { sion created in } 2014 \text { for } \\
\text { exploitation of uncon- } \\
\text { ventional resources }\end{array}$ & $\begin{array}{l}\text { Concession arrangement } \\
\text { with a standard model } \\
\text { containing incentives } \\
\text { for unconventional } \\
\text { resources; special regu- } \\
\text { lations and procedures } \\
\text { in place for claims of } \\
\text { overlapping rights- } \\
\text { holders }\end{array}$ & $\begin{array}{l}\text { Licences evolved from exist- } \\
\text { ing conventional pattern } \\
\text { to include Retention } \\
\text { Areas and Development } \\
\text { Areas; consents required } \\
\text { beyond those in the licen- } \\
\text { ces (including environ- } \\
\text { mental, planning \& land } \\
\text { access); fast track process- } \\
\text { ing of applications intro- } \\
\text { duced; dedicated } \\
\text { government office for } \\
\text { shale gas and oil promo- } \\
\text { tion set up }\end{array}$ \\
\hline $\begin{array}{l}\text { Players: corporate invest- } \\
\text { ors available with ex- } \\
\text { pertise and access to } \\
\text { capital/service } \\
\text { companies }\end{array}$ & $\begin{array}{l}\text { Dominated by large for- } \\
\text { eign companies; local } \\
\text { content policy to build } \\
\text { up supply chain indus- } \\
\text { try, especially at provin- } \\
\text { cial level }\end{array}$ & $\begin{array}{l}\text { Companies with a long } \\
\text { track record in devel- } \\
\text { oping unconventional } \\
\text { hydrocarbons, such as } \\
\text { ExxonMobil and } \\
\text { ConocoPhillips have } \\
\text { signed agreements for } \\
\text { the exploration of un- } \\
\text { conventional hydrocar- } \\
\text { bons. The NOC, } \\
\text { Ecopetrol, has shown } \\
\text { interest, and has pro- } \\
\text { posed a pilot project, } \\
\text { to dissipate any fears } \\
\text { from the local popula- } \\
\text { tion. There are even } \\
\text { possibilities to create a } \\
\text { spin-off company dedi- } \\
\text { cated specially to these } \\
\text { activities. }\end{array}$ & $\begin{array}{l}\text { Limited corporate interest } \\
\text { to date but regime open } \\
\text { to foreign and domestic } \\
\text { investors }\end{array}$ \\
\hline
\end{tabular}


Table 3. (continued)

\begin{tabular}{|c|c|c|c|}
\hline Shale 1.0: US Template & Argentina & Colombia & $U K$ \\
\hline $\begin{array}{l}\text { Pipeline infrastructure \& } \\
\text { capacity }\end{array}$ & $\begin{array}{l}\text { Bottleneck; funding and } \\
\text { regulatory issues need to } \\
\text { be addressed if US } \\
\text { model of exporting shale } \\
\text { gas is to be followed }\end{array}$ & $\begin{array}{l}\text { The infrastructure has } \\
\text { been developed for the } \\
\text { main conventional } \\
\text { fields, for local con- } \\
\text { sumption and export. } \\
\text { New investment has } \\
\text { been made on the in- } \\
\text { frastructure that con- } \\
\text { nects the principal } \\
\text { areas where unconven- } \\
\text { tional hydrocarbons } \\
\text { may be located; how- } \\
\text { ever, some of it needs } \\
\text { to be expanded or } \\
\text { renewed. }\end{array}$ & $\begin{array}{l}\text { Provision made for } \\
\text { improved rules on } \\
\text { infrastructure }\end{array}$ \\
\hline $\begin{array}{l}\text { Water supply and evolv- } \\
\text { ing regulation }\end{array}$ & $\begin{array}{l}\text { Regulatory controls in } \\
\text { place over water supply }\end{array}$ & $\begin{array}{l}\text { Based on the American } \\
\text { experience the environ- } \\
\text { mental authority has } \\
\text { developed a very strict } \\
\text { regulation for the use } \\
\text { of water. However, } \\
\text { practices such as re-in- } \\
\text { jection are possible. } \\
\text { There are requirements } \\
\text { for drilling, such as the } \\
\text { need of EIA to identify } \\
\text { and protect aquifers. }\end{array}$ & $\begin{array}{l}\text { Re-injection of water pro- } \\
\text { hibited; water abstraction } \\
\text { licence required; ground- } \\
\text { water activity permit } \\
\text { required; disposal of water } \\
\text { may be an issue for regu- } \\
\text { lation if production takes } \\
\text { off }\end{array}$ \\
\hline $\begin{array}{l}\text { Location in areas of low } \\
\text { population density, } \\
\text { limiting social licence } \\
\text { to operate barriers }\end{array}$ & $\begin{array}{c}\text { Locations are far from } \\
\text { population centres }\end{array}$ & $\begin{array}{l}\text { Population density in } \\
\text { areas of exploration is } \\
\text { not very high. } \\
\text { However, agricultural } \\
\text { activity in the areas has } \\
\text { created concerns on } \\
\text { water resources, and } \\
\text { the potential effects } \\
\text { that unconventional } \\
\text { hydrocarbons activities } \\
\text { may have on crops and } \\
\text { cattle. }\end{array}$ & $\begin{array}{l}\text { Population density high so } \\
\text { social licence is an issue } \\
\text { but note regulatory diver- } \\
\text { gence inside UK with } \\
\text { moratorium in Scotland }\end{array}$ \\
\hline Deep capital markets & Not available locally & Not available locally & $\begin{array}{l}\text { Available but no production } \\
\text { yet }\end{array}$ \\
\hline
\end{tabular}


Table 3. (continued)

\begin{tabular}{|c|c|c|c|}
\hline Shale 1.0: US Template & Argentina & Colombia & $U K$ \\
\hline $\begin{array}{l}\text { High natural gas prices/ } \\
\text { gas demand }\end{array}$ & $\begin{array}{l}\text { Need to export gas rather } \\
\text { than use for domestic } \\
\text { consumption }\end{array}$ & $\begin{array}{l}\text { Prices of gas are not } \\
\text { high. Due to climate } \\
\text { change and local issues } \\
\text { to produce electricity, } \\
\text { there is a projection of } \\
\text { a high increase on the } \\
\text { demand for gas in the } \\
\text { next decades. }\end{array}$ & Yes \\
\hline Royalties \& taxes & $\begin{array}{l}\text { Provinces take } 12 \% \text { royalty } \\
\text { share on sale of hydro- } \\
\text { carbons; payments in } \\
\text { kind are possible }\end{array}$ & $\begin{array}{l}\text { Tax incentive: royalty is } \\
\text { only } 60 \% \text { of conven- } \\
\text { tional production }\end{array}$ & $\begin{array}{l}\text { Proposal to create allowance } \\
\text { to reduce tax potion on } \\
\text { income from companies } \\
\text { from } 62 \% \text { to } 30 \%\end{array}$ \\
\hline
\end{tabular}

